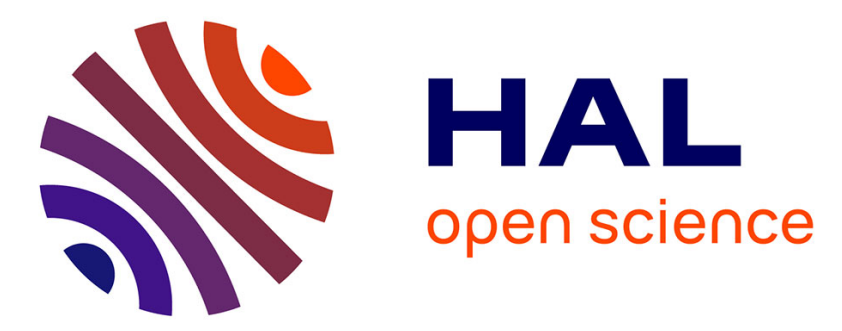

\title{
Effect of the dietary intake of melatonin-and hydroxytyrosol-rich wines by healthy female volunteers on the systemic lipidomic-related oxylipins
}

Javier Marhuenda, Sonia Medina, Pedro Martínez-Hernández, Simon Arina, Pilar Zafrilla, Juana Mulero, Camille Oger, Jean-Marie Galano, Thierry

Durand, Antonio Solana, et al.

\section{To cite this version:}

Javier Marhuenda, Sonia Medina, Pedro Martínez-Hernández, Simon Arina, Pilar Zafrilla, et al.. Effect of the dietary intake of melatonin-and hydroxytyrosol-rich wines by healthy female volunteers on the systemic lipidomic-related oxylipins. Food and Function, 2017, 8 (10), pp.3745-3757. 10.1039/c7fo01081h . hal-02594444

\section{HAL Id: hal-02594444 \\ https://hal.science/hal-02594444}

Submitted on 15 May 2020

HAL is a multi-disciplinary open access archive for the deposit and dissemination of scientific research documents, whether they are published or not. The documents may come from teaching and research institutions in France or abroad, or from public or private research centers.
L'archive ouverte pluridisciplinaire HAL, est destinée au dépôt et à la diffusion de documents scientifiques de niveau recherche, publiés ou non, émanant des établissements d'enseignement et de recherche français ou étrangers, des laboratoires publics ou privés. 


\title{
Effect of the dietary intake of melatonin- and hydroxytyrosol-rich wines by healthy female volunteers on the systemic lipidomic-related oxylipins
}

\author{
Javier Marhuenda, ${ }^{\text {a,b }}$ Sonia Medina, ${ }^{\star a}$ Pedro Martínez-Hernández, ${ }^{\mathrm{c}, \mathrm{d}}$ Simon Arina, ${ }^{\mathrm{d}}$ \\ Pilar Zafrilla, ${ }^{\mathrm{b}}$ Juana Mulero, ${ }^{\mathrm{b}}$ Camille Oger, ${ }^{\mathrm{e}}$ Jean-Marie Galano, ${ }^{\mathrm{e}}$ Thierry Durand, \\ Antonio Solana, ${ }^{a}$ Federico Ferreres, ${ }^{a}$ Juan José López-Garcia ${ }^{f}$ and \\ Angel Gil-Izquierdo (D) *a
}

\begin{abstract}
Oxylipins are lipid mediators involved in the physiopathology of all organs. Moreover, isoprostanes have been established as general and reliable in vivo oxidative stress biomarkers. Red wine has proved to exert several benefits through the maintenance of the oxidative balance of the organism. Antiradical scavenging capacity has been mainly attributed to polyphenols. However, melatonin and hydroxytyrosol should be taken into account as potent antiradical agents. The present research aimed to clarify the situation of enzymatic and oxidative injury and eicosanoid urinary excretion related to the intake of three kinds of red wines and their primary musts. Judging by the reduction in the excretion of isoprostanes, red wine consumption exhibited the highest antioxidant protection against oxidative stress, attributed to its OHTyr content $(p<0.05)$, and to a lesser extent to its MEL content. Similarly, the intake of red wine leads to the cardioprotective effect due to the reduction in the urinary excretion of the pro-inflammatory prostaglandin 2,3-dinor-11- $\beta-\mathrm{PGF}_{2 \alpha}$, besides the increase in the vasodilator prostaglandin $\mathrm{PGE}_{1}$, mediated by the melatonin $(p<0.05)$ and hydroxytyrosol $(p<0.05)$ contents. In conclusion, red wine (especially nonaged wine) exerts a higher in vivo antioxidant capacity than must or alcohol.
\end{abstract}

\section{Introduction}

Lipid peroxidation products have been investigated in order to determine their use as biomarkers of oxidative status in different plant and mammalian systems. Linolenic acid (ALA), arachidonic acid (AA), adrenic acid (AdA), eicosapentaenoic acid (EPA) and docosahexaenoic acid (DHA) are commonly studied fatty $\operatorname{acids}^{1-3}$ which result in phytoprostanes

\footnotetext{
${ }^{a}$ Research Group on Quality, Safety and Bioactivity of Plant Foods, Department of Food Science and Technology, CEBAS (CSIC), P.O. Box 164, 30100 Campus University Espinardo, Murcia, Spain. E-mail: smescudero@cebas.csic.es, angelgil@cebas.csic.es; Fax: +34968396213 ; Tel: +34 968396200, ext. 6363 ${ }^{b}$ Department of Food Technology and Nutrition, Catholic University of San Antonio, Murcia 30107, Spain

${ }^{c}$ Lab of Clinical Analysis, University Hospital Virgen de la Arrixaca, Murcia, Spain

${ }^{d}$ Bodegas Baigorri S.A.U., Ctra. Vitoria-Logroño Km. 53, 01307 Samaniego, Álava, Spain

${ }^{e}$ Institut des Biomolécules Max Mousseron, UMR 5247 CNRS-University of Montpellier - ENSCM, Montpellier, France

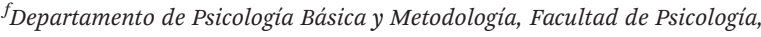
Campus de Espinardo s/n, 30100 Espinardo, Murcia, Spain
}

(PhytoPs), ${ }^{2,4}$ isoprostanes (IsoPs), ${ }^{1,3} \quad \mathrm{~F}_{2}$-dihomo-isoprostanes ( $\mathrm{F}_{2}$-dihomo-IsoPs), $\mathrm{F}_{3}$-neuroprostanes $\left(\mathrm{F}_{3}\right.$-NeuroPs $)$ and $\mathrm{F}_{4}$ neuroprostanes ( $\mathrm{F}_{4}$-NeuroPs), respectively. ${ }^{1}$

IsoPs have been established as general and reliable "in vivo" oxidative stress biomarkers, and their presence in several clinical physiological and pathological conditions such as aging, cardiovascular disorders, cancer, and neurological pathologies has been established. ${ }^{3,5,6}$ They are prostaglandin-like compounds, produced by the non-enzymatic peroxidation of AA, normally catalyzed by free radicals. ${ }^{6,7}$

Other metabolites derived from the oxidation of AA are prostaglandins (PGs); however, they are formed enzymatically (in contrast to IsoPs). Their formation is regulated by cyclooxygenase (COX) from fatty acids like AA. ${ }^{8}$ The rates of action of PGs are large since they are able to exert physiological effects related to inflammation, fever or pain, thanks to prostaglandin signaling through specific $G$ protein-coupled receptors. ${ }^{9,10}$ Both PG and IsoPs are defined as eicosanoids, considered as lipid mediators, involved in the physiopathology of all organs, tissues, and cells, being associated with homeostasis, biological functions and inflammation. ${ }^{11}$ 
A Mediterranean diet (MD) has been proved to exert several benefits in order to maintain the redox balance. Antioxidants, mainly polyphenols, have been thought to be mainly responsible for the antiradical effects related to $\mathrm{MD} .^{12}$ Wine is a representative alcoholic component of the $\mathrm{MD}$, considered responsible for the "French paradox". ${ }^{13}$ Red wine polyphenols have demonstrated in vivo and in vitro antioxidant capacity, ${ }^{12,14}$ leading to the protection against cardiovascular and degenerative diseases, besides some cancers and inflammation processes. $^{15}$ In fact, ethanol has been considered to exert antioxidant capacity in vivo, ${ }^{13,16,17}$ so alcohol could be partially responsible for the effects of red wine.

Despite these beneficial effects, polyphenols have demonstrated a very low bioavailability, both in vivo and in vitro. ${ }^{12,15,18}$ Concerning the low absorption of polyphenols, other compounds such as melatonin (MEL) and hydroxytyrosol (OHTyr) and its metabolites from colonic microflora metabolism could be partially responsible for the antioxidant benefits of red wine. ${ }^{19}$ Both MEL and OHTyr act as radical scavengers, regulating the oxidation status of the organism. ${ }^{19-21}$ They are not only able to scavenge oxidants, but they have also demonstrated the endogenous enzymatic activation of the antioxidant defense system and cardioprotective properties. ${ }^{19,20,22}$ They are even able to trespass physiological barriers, crossing the blood-brain barrier. Therefore, MEL and OHTyr can act as local and general antioxidants, exerting antiradical protection when needed. ${ }^{23,24}$

The present research aims to clarify the state of the art about the systemic lipid peroxidation markers and enzymatic lipid oxidation in the human body related to the effect of the intake of a cup of red wine, paying attention to its bioactive compounds in general and OHTyr/MEL in particular, by conducting an in vivo study with 18 female volunteers.

\section{Materials and methods}

\section{Chemicals and reagents}

HPLC-grade ACN and methanol were purchased from Scharlau Chemie (Barcelona, Spain). Ultrapure water (Milli-Q) was obtained from Milli-Q Gradient A10 system (Millipore, Bedford, MA). $\beta$-Glucuronidase, type $\mathrm{H} 2$ from Helix pomatia and BIS-TRIS (bis-(2-hydroxyethyl)-amino-tris(hydroxymethyl)methane) were obtained from Sigma-Aldrich (St. Louis, MO, USA). Strata X-AW cartridges, $100 \mathrm{mg} 3 \mathrm{~mL}^{-1}$, were obtained from Phenomenex (Torrance, CA, USA). 15- $\mathrm{F}_{2 \mathrm{t}}$-IsoP, 15-epi-15$\mathrm{F}_{2 \mathrm{t}}$-IsoP, ent-15-epi-15- $\mathrm{F}_{2 \mathrm{t}}$-IsoP, 2,3-dinor-15- $\mathrm{F}_{2 \mathrm{t}}$-IsoP, 2,3-dinor-

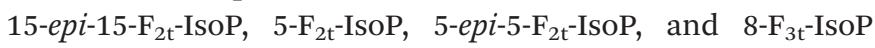
were synthesized according to our published procedures. ${ }^{25-27}$ The other isoprostanes and prostaglandins were purchased from Cayman Chemical (Ann Arbor, MI, USA). These compounds were: PGDM, $\mathrm{PGD}_{2}$, Tetranor-PGDM lactone, 11$\beta$-PGF ${ }_{2 \alpha}, 2,3$-dinor-11 $\beta$-PGF $2 \alpha$, Tetranor-PGDM, Tetranor-PGJM, $\mathrm{PGE}_{2}, 20-\mathrm{OH}-\mathrm{PGE}_{2}$, Tetranor-PGEM, Tetranor-PGAM, TetranorPGFM, 15-keto-PGF ${ }_{2 \alpha}, \quad 20-\mathrm{OH}-\mathrm{PGF}_{2 \alpha}, \quad$ 19(R)-OH-PGF $2 \alpha, \quad 2,3-$ dinor-6-keto-PGF ${ }_{1 \alpha}, \quad$ 6-keto- $\mathrm{PGF}_{1 \alpha}$, ent-PGF ${ }_{2 \alpha}, \quad$ 15-keto-15- $\mathrm{F}_{2 \mathrm{t}^{-}}$
IsoP, 9-epi-15- $\mathrm{F}_{2 \mathrm{t}}$-IsoP, 15-keto-15- $\mathrm{E}_{2 \mathrm{t}}$-IsoP, 15-epi-15- $\mathrm{E}_{2 \mathrm{t}}$-IsoP,

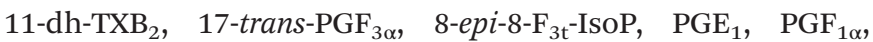
15- $\mathrm{E}_{1 \mathrm{t}}$-IsoP, 15- $\mathrm{F}_{1 \mathrm{t}}$-IsoP, U-44619, and U-44069.

\section{Red wine samples assayed in this clinical and nutritional trial}

The description of red wines and their primary musts was provided in our previous studies. ${ }^{28,29}$ The red wines were provided by the Baigorri winery (Bodegas Baigorri S.A.U, Samaniego, Álava). With the aim to compare different vinification and aging procedures, three different wines were chosen and named as follows: "Baigorri carbonic maceration 2010", "Baigorri aged 2007" and "Baigorri high expression 2010". Wines were stored between $12^{\circ} \mathrm{C}$ and $14{ }^{\circ} \mathrm{C}$ after bottling, leading to a correct maintenance. The primary musts of the wine samples were stored at $-20{ }^{\circ} \mathrm{C}$ after the harvest of the grapes, avoiding fermentation. The use of the primary musts of the wine samples allowed the determination of the differences between the wines arising from the differences in the winemaking processes, avoiding any differences in the grape variety or harvesting procedure from must to wine.

\section{Study design}

The characteristics of the present study have been described in our previous reports, ${ }^{28,29}$ being previously approved by the Bioethics Committee of the Catholic University San Antonio de Murcia (UCAM). The study included a total of $18(N=18)$ healthy female volunteers, between 18 and 27 years of age (the characteristics are shown in Table 1). Importantly, all individuals in this study were nonsmokers and during the study the women were not in their menstrual days. Informed and signed consent of each individual involved in the trial was obtained. The development of the study was double-blind, crossover and placebo-controlled, carried out in four stages. At the beginning of each stage, the volunteers $(N=18)$ were divided into two equal groups $\left(N_{1}=9\right.$ and $\left.N_{2}=9\right)$ in order to facilitate the crossover of the study. The structure of the stages consisted of 48 hours of urine collection since the beginning of the treatment, followed by a 72 hour washout period. Finally, after the washout period, the crossover was developed, collecting the urine of the volunteers in the following 48 hours. Afterwards, each stage was in turn separated by washout periods of

Table 1 Physical and clinical parameters of the participants $(N=18)$

\begin{tabular}{|c|c|c|}
\hline Parameters & Mean & $\mathrm{SD}$ \\
\hline Age (years) & 22.5 & 6.3 \\
\hline Weight (kg) & 64.3 & 16.4 \\
\hline Height (cm) & 164.1 & 17.7 \\
\hline BMI $\left(\mathrm{kg} \mathrm{m}^{-2}\right)$ & 23.54 & 1.07 \\
\hline Glucose $\left(\mathrm{mg} \mathrm{dL}^{-1}\right)$ & 87.2 & 7.7 \\
\hline Urea $\left(\mathrm{mg} \mathrm{dL}^{-1}\right)$ & 28.7 & 6.6 \\
\hline Creatinine $\left(\mathrm{mg} \mathrm{dL}^{-1}\right)$ & 0.7 & 0.1 \\
\hline Uric acid $\left(\mathrm{mg} \mathrm{dL}^{-1}\right)$ & 3.8 & 0.8 \\
\hline Cholesterol (mg dL $\left.{ }^{-1}\right)$ & 190.1 & 31.7 \\
\hline Triglycerides $\left(\mathrm{mg} \mathrm{dL}^{-1}\right)$ & 87.5 & 39.3 \\
\hline HDL-Cholesterol $\left(\mathrm{mg} \mathrm{dL}^{-1}\right)$ & 70.9 & 18.8 \\
\hline LDL-Cholesterol $\left(\mathrm{mg} \mathrm{dL}^{-1}\right)$ & 101.1 & 24.7 \\
\hline
\end{tabular}


72 hours too. The graphical distribution of the different stages developed in the present study is shown in Fig. 1.

Urine samples were obtained equally in all the stages of the study (graphically represented in Fig. 1). At 0 hours, the first urine in the morning was obtained both before and after the crossover. Additionally, urine samples were collected from 0 to 48 hours in order to establish the in vivo effects of the intake of the different beverages. Importantly, although the measurements were performed in the urine of 48 hours, the data obtained are expressed in $\mu \mathrm{g} 24 \mathrm{~h}^{-1}$ in order to facilitate the comparison with previously reported data.

\section{Extraction and determination of melatonin and phenolics by UHPLC-QqQ-MS/MS}

The methods used for the characterization of the samples were described in our previous reports. ${ }^{28,29}$ The different phenolic compounds detected in the samples of wine and must were identified by their UV-Vis spectra and chromatographic comparison with authentic commercial markers. ${ }^{18,30}$ Anthocyanins were quantified at $520 \mathrm{~nm}$ by comparison with malvidin-3glucoside $(\mathrm{LOD}=0.074 \mathrm{ppm}, \mathrm{LQD}=0.240 \mathrm{ppm}$ ) and flavonols were quantified at $360 \mathrm{~nm}$ by comparison with quercetin-3- rutinoside $(\mathrm{LOD}=0.123 \mathrm{ppm}, \quad \mathrm{LQD}=0.409 \mathrm{ppm})$. Hydroxycinnamic acid derivatives were quantified at $320 \mathrm{~nm}$ by comparison with caffeic acid (LOD $=0.064$ ppm, LQD $=$ $0.212 \mathrm{ppm}$ ) and finally, $E$-stilbenes were quantified by comparison with trans-resveratrol $(\mathrm{LOD}=0.024 \mathrm{ppm}, \mathrm{LQD}=$ $0.074 \mathrm{ppm})$.

For the determination of OHTyr and its metabolites, a UHPLC coupled to a 6460 QqQ-MS/MS (Agilent Technologies, Waldbronn, Germany) was used, following the method designed by Domínguez-Perles et al. (2015). ${ }^{31}$

For the analysis of MEL and serotonin, the extraction procedure for the wines and musts was as previously described. ${ }^{32}$ The separation and determination of MEL and serotonin was performed using a UHPLC coupled to a 6460 QqQ-MS/MS (Agilent Technologies, Waldbronn, Germany) and a Waters Acquity UHPLC BEH C 18 $1.7 \mu \mathrm{m} 2.1 \times 50 \mathrm{~mm}$ column.

\section{Sample preparation for eicosanoid analysis}

The extraction of eicosanoids in urine was carried out following the method developed by ref. 33. All solutions were stored at $-80^{\circ} \mathrm{C}$. The eicosanoid concentrations were calculated from standard curves freshly prepared each day.

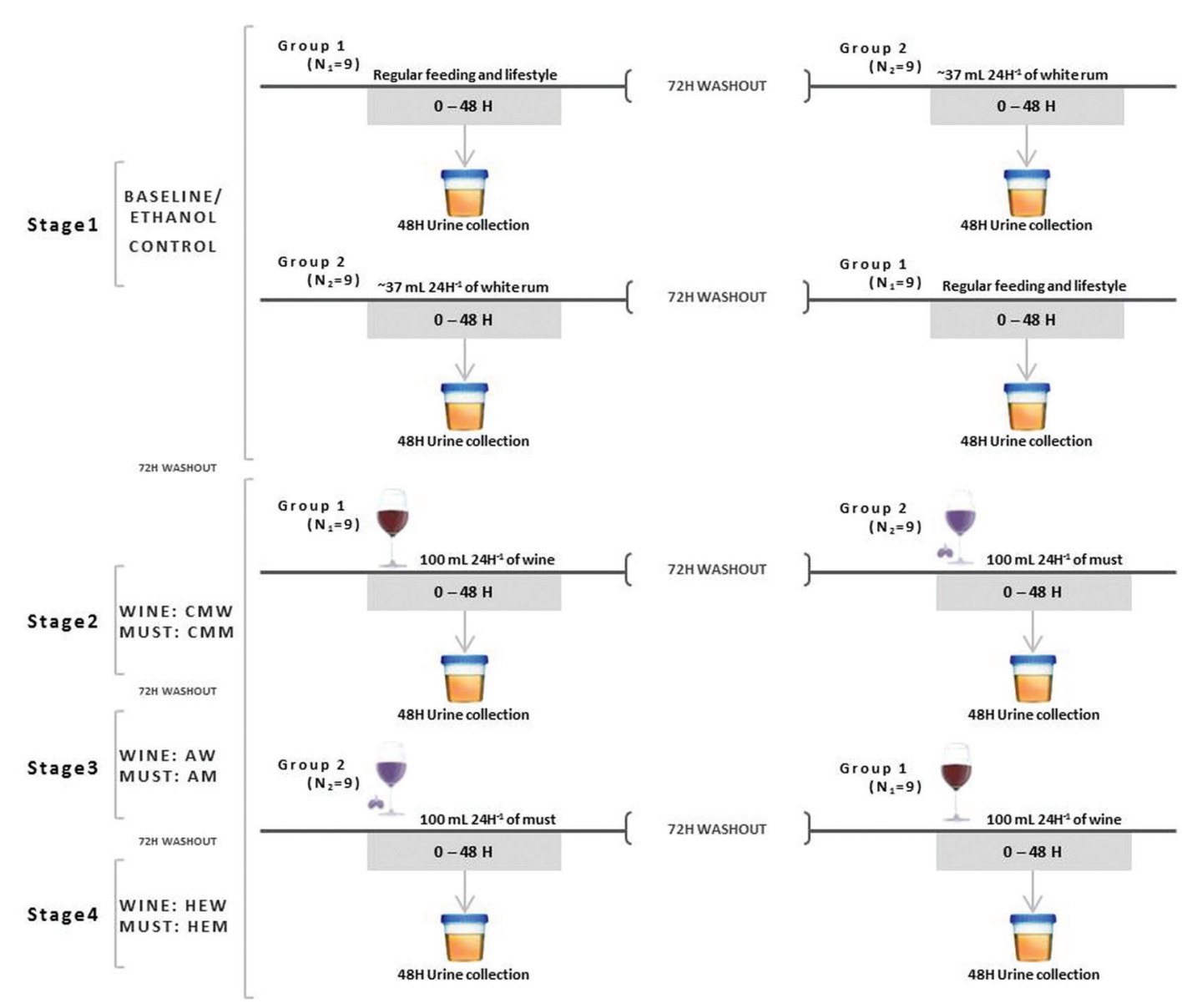

Fig. 1 Graphical representation of the in vivo assay, divided into four stages. Stages 2, 3 and 4 were similar but the beverage drunk changed between stages. A period of 72 hours was included both between stages and before the crossover. CMW/CMM: carbonic maceration wine/must; AW/AM: aged wine/must; HEW/HEM: high expression wine/must. 
For the enzymatic hydrolysis to remove the glucuronide and sulfate conjugates, the enzyme $\beta$-glucuronidase from Helix pomatia was used according to ref. 33 . Before the analysis by UHPLC-QqQ-MS/MS, the samples were subjected to solid phase extraction (SPE) using a Strata X-AW cartridge (100 mg $3 \mathrm{~mL}^{-1}$ ) according to the procedure described by Medina et al. (2015). ${ }^{33}$ The analytes were eluted with $1 \mathrm{~mL}$ of $\mathrm{MeOH}$ and dried under vacuum using a SpeedVac concentrator (Savant SPD121P, Thermo Scientific, MA, USA). The dry extracts were reconstituted with $\mathrm{A}: \mathrm{B}$ phases $(90: 10, \mathrm{v}: \mathrm{v})$ and filtered through a $0.45 \mu \mathrm{m}$ filter (Millipore, MA, USA). Samples were finally injected and analyzed by UHPLC-QqQ-MS/MS.

\section{UHPLC-QqQ-MS/MS analysis of urinary eicosanoids}

LC-MS/MS has demonstrated to be the most specific and versatile method to determine the biomarkers of lipid peroxidation. ${ }^{34}$ Eicosanoids were separated using a UHPLC system coupled to a 6460 triple quadrupole tandem mass spectrometer (Agilent Technologies, Waldbronn, Germany). Chromatographic separation was carried out on an ACQUITY BEH $\mathrm{C}_{18}$ column $(2.1 \times 50 \mathrm{~mm}, 1.7 \mu \mathrm{m}$ pore size) (Waters, MA, USA), and the column temperatures were $6{ }^{\circ} \mathrm{C}$ both left and right. Sample analysis was carried out following the method previously reported by Medina et al. (2015); ${ }^{33}$ the multiple reaction monitoring (MRM) mode was performed using the negative electrospray ionization (ESI) mode. The mobile phases used were A (water) and B (methanol), both containing $0.01 \%$ of acetic acid (v:v). The operating conditions for MS parameters and flow rate were defined by Medina et al. (2015). ${ }^{33}$ The injection volume was $20 \mu \mathrm{L}$ in UHPLC-QqQ-MS/ MS. Data acquisition and processing was performed using MassHunter software version B.04.00 (Agilent Technologies, Walbronn, Germany). Finally, the amount of eicosanoids in urine was calculated from the area ratio of the ion peaks of the compounds over the corresponding standards.

\section{Statistical analysis}

The analysis of variance (ANOVA; Duncan) was applied to establish significant differences between the means obtained during the fermentation process. In order to understand the changes observed in the different samples and the influence of the different bioactive compounds, a statistical procedure was developed that has been described in our previous studies. $^{28,29}$ Simple regression was performed and the results obtained were compared with the results of multiple regression analysis in stepwise mode, in order to establish a realistic relationship. These analyses were performed with SPSS version 21 software (SPSS Inc., Chicago, IL, USA).

\section{Results}

\section{Qualitative and quantitative analysis of melatonin and phenolics in wines and musts}

The results relating to the content of bioactive compounds in different wine and must samples have been reported and discussed in our previous studies. ${ }^{28,29}$ In order to help understand the study, the results are summarized in the present paper. The concentrations of the different bioactive compounds are shown in Table 2 (describing the content of MEL, OHTyr and its metabolites) and Table 3 (showing the content of phenolic compounds).

Briefly, the wines showed a higher content of MEL, while the musts contained very small amounts of this compound. In wines, the highest MEL concentration was found in carbonic maceration wine (CMW) $\left(161.83 \pm 7.14 \mathrm{ng} \mathrm{mL} \mathrm{mL}^{-1}\right)$, while aged wine $(\mathrm{AW})\left(26.31 \pm 1.35 \mathrm{ng} \mathrm{mL}^{-1}\right)$ and high expression wine $\left(\right.$ HEW) $\left(19.63 \pm 1.14 \mathrm{ng} \mathrm{mL}^{-1}\right)$ showed minor contents $(p<$ $0.01)$ but similar concentrations $(p>0.05)$.

Musts showed high amounts of HV-Acid, but minor contents of HV-Alc and a very slight presence of OHTyr. HV-Alc followed a trend opposite to that of HV-Acid, with its concentration increasing after winemaking for CMW and AW, but not HEW (Table 2). The most important difference between the wines and musts was the increment of OHTyr after vinification $(p<0.05)$. As shown in Table 2, HEW showed the highest OHTyr concentration of all the beverages (35.11 \pm 2.51 $\left.\mathrm{ng} \mathrm{mL}^{-1}\right)$, followed by AW $\left(29.65 \pm 0.46 \mathrm{ng} \mathrm{mL}^{-1}\right)$ and CMW $\left(16.13 \pm 2.98 \mathrm{ng} \mathrm{mL}{ }^{-1}\right)$.

The concentration of phenolic compounds from the wines and musts is shown in Table 3. Anthocyanins were the major phenolic compounds found in the wines and musts, underlining malvidin-3-O-glucoside as the major anthocyanin both in

Table 2 Characterization of the bioactive compounds of red wines and musts and the white rum ethanol content

\begin{tabular}{|c|c|c|c|c|c|c|}
\hline & \multirow[b]{2}{*}{ Tryptophan $\left(\mathrm{ng} \mathrm{mL}^{-1}\right)$} & \multirow[b]{2}{*}{ Melatonin $\left(\mathrm{ng} \mathrm{mL}^{-1}\right)$} & \multirow[b]{2}{*}{ Ethanol (gram per dose $\mathrm{e}^{*}$ ) } & \multicolumn{3}{|c|}{ Hydroxytyrosol metabolites (ng $\mathrm{mL}^{-1}$ ) } \\
\hline & & & & Homovanillic acid & Homovanillic alcohol & Hydroxytyrosol \\
\hline WR & - & - & 4.14 & - & - & - \\
\hline CMW & $79.13 \pm 2.26^{\mathrm{c}}$ & $161.83 \pm 7.14^{\mathrm{a}}$ & 4.14 & $83.46 \pm 13.59^{\mathrm{c}}$ & $189.23 \pm 8.71^{\mathrm{a}}$ & $16.13 \pm 2.98^{\mathrm{b}}$ \\
\hline CMM & $155.72 \pm 14.69^{\mathrm{b}}$ & $0.41 \pm 0.039^{\mathrm{d}}$ & - & $130.76 \pm 1.32^{\mathrm{a}}$ & $14.63 \pm 0.17^{\mathrm{c}}$ & $0.53 \pm 0.05^{\mathrm{c}}$ \\
\hline $\mathrm{AW}$ & $2.79 \pm 0.30^{\mathrm{e}}$ & $26.31 \pm 1.35^{\mathrm{b}}$ & 4.14 & $74.38 \pm 0.68^{\mathrm{c}}$ & $65.51 \pm 1.31^{\mathrm{b}}$ & $29.65 \pm 0.46^{\mathrm{a}}$ \\
\hline AM & $144.29 \pm 11.02^{\mathrm{b}}$ & $1.24 \pm 0.13^{\mathrm{c}, \mathrm{d}}$ & - & $112.41 \pm 3.12^{\mathrm{a}, \mathrm{b}}$ & $16.22 \pm 1.02^{\mathrm{c}}$ & $0.96 \pm 0.09^{c}$ \\
\hline HEW & $17.71 \pm 1.76^{\mathrm{d}}$ & $19.63 \pm 1.14^{\mathrm{b}}$ & 4.14 & $75.94 \pm 7.29^{\mathrm{c}}$ & $51.56 \pm 6.27^{\mathrm{b}}$ & $35.11 \pm 2.51^{\mathrm{a}}$ \\
\hline HEM & $573.08 \pm 38.01^{\mathrm{a}}$ & $0.03 \pm 0.004^{\mathrm{d}}$ & - & $101.04 \pm 2.21^{\mathrm{a}, \mathrm{b}}$ & $60.59 \pm 1.31^{\mathrm{b}}$ & $0.54 \pm 0.03^{c}$ \\
\hline
\end{tabular}

WR: white rum; CMW/CMM: carbonic maceration wine/must; AW/AM: aged wine/must; HEW/HEM: high expression wine/must. *It is considered as the total dose ingested during 48 hours: $74 \mathrm{~mL}$ of white rum and $200 \mathrm{~mL}$ of wine and must. 
Table 3 Polyphenolic content of red wines and musts

\begin{tabular}{|c|c|c|c|c|c|c|}
\hline & CMW & CMM & AW & $\mathrm{AM}$ & HEW & HEM \\
\hline Delphinidin-3-O-glucoside & $55.97 \pm 2.18^{\mathrm{a}}$ & $12.11 \pm 0.56^{\mathrm{c}, \mathrm{d}}$ & $39.81 \pm 0.48^{\mathrm{b}}$ & $12.96 \pm 1.10^{\mathrm{c}, \mathrm{d}}$ & $11.36 \pm 0.47^{\mathrm{d}}$ & $14.63 \pm 1.14^{\mathrm{c}}$ \\
\hline Cyanidin-3-O-glucoside & $2.45 \pm 0.05^{\mathrm{b}, \mathrm{c}}$ & $4.03 \pm 0.17^{\mathrm{b}}$ & $3.44 \pm 0.09^{\mathrm{b}, \mathrm{c}}$ & $3.69 \pm 0.08^{\mathrm{b}}$ & $0.60 \pm 0.04^{\mathrm{c}}$ & $7.29 \pm 0.88^{\mathrm{a}}$ \\
\hline Petunidin-3-O-glucoside & $54.73 \pm 1.26^{\mathrm{a}}$ & $9.13 \pm 0.59^{\mathrm{d}}$ & $30.21 \pm 0.27^{\mathrm{b}}$ & $9.12 \pm 0.98^{\mathrm{d}}$ & $8.17 \pm 0.20^{\mathrm{d}}$ & $13.85 \pm 0.95^{\mathrm{c}}$ \\
\hline Peonidin-3-O-glucoside & $11.77 \pm 1.04^{\mathrm{b}}$ & $7.36 \pm 1.52^{\mathrm{c}}$ & $10.96 \pm 0.35^{\mathrm{b}}$ & $7.38 \pm 0.74^{\mathrm{c}}$ & $3.37 \pm 0.04^{\mathrm{d}}$ & $14.66 \pm 1.39^{\mathrm{a}}$ \\
\hline Malvidin-3-O-glucoside & $236.87 \pm 10.00^{\mathrm{a}}$ & $35.80 \pm 2.30^{\mathrm{d}}$ & $90.10 \pm 5.09^{\mathrm{b}}$ & $38.53 \pm 20.00^{\mathrm{d}}$ & $35.19 \pm 0.61^{\mathrm{c}}$ & $74.16 \pm 3.29^{\mathrm{d}}$ \\
\hline Total anthocyanins & $361.79 \pm 11.27^{\mathrm{a}}$ & $68.43 \pm 3.71^{\mathrm{d}}$ & $174.53 \pm 5.98^{\mathrm{b}}$ & $71.68 \pm 3.25^{\mathrm{d}}$ & $58.68 \pm 0.74^{\mathrm{c}}$ & $124.59 \pm 4.56^{\mathrm{d}}$ \\
\hline Caftaric acid & $45.09 \pm 4.52^{\mathrm{b}, \mathrm{c}}$ & $0.59 \pm 0.02^{\mathrm{d}}$ & $48.81 \pm 0.03^{\mathrm{a}, \mathrm{b}}$ & $0.31 \pm 0.02^{\mathrm{d}}$ & $55.70 \pm 4.73^{\mathrm{a}}$ & $2.35 \pm 0.12^{\mathrm{d}}$ \\
\hline$p$-Coumaric acid & $1.30 \pm 0.07^{\mathrm{c}}$ & $\mathrm{ND}$ & $10.59 \pm 0.73^{\mathrm{b}}$ & ND & $14.42 \pm 1.04^{\mathrm{a}}$ & ND \\
\hline Fertaric acid & $0.76 \pm 0.04^{\mathrm{c}}$ & ND & $2.40 \pm 0.08^{\mathrm{b}}$ & ND & $5.20 \pm 0.30^{\mathrm{a}}$ & ND \\
\hline Coutaric acid & $40.82 \pm 1.75^{\mathrm{a}}$ & $0.39 \pm 0.06^{\mathrm{d}}$ & $13.69 \pm 0.32^{\mathrm{c}}$ & $0.28 \pm 0.02^{\mathrm{d}}$ & $20.54 \pm 0.71^{\mathrm{b}}$ & $1.13 \pm 0.10^{\mathrm{d}}$ \\
\hline Total hydroxycinnamic derivatives & $87.96 \pm 6.39^{\mathrm{a}}$ & $0.98 \pm 0.08^{\mathrm{c}}$ & $75.50 \pm 1.15^{\mathrm{b}}$ & $0.59 \pm 0.04^{\mathrm{c}}$ & $95.85 \pm 6.77^{\mathrm{a}}$ & $3.48 \pm 0.22^{\mathrm{c}}$ \\
\hline Myricetin-3-O-glucoside & $3.96 \pm 0.06^{\mathrm{a}}$ & $1.06 \pm 0.04^{\mathrm{c}}$ & $4.21 \pm 0.23^{\mathrm{a}}$ & $1.00 \pm 0.04^{\mathrm{c}}$ & $2.84 \pm 0.26^{\mathrm{b}}$ & $1.22 \pm 0.05^{\mathrm{c}}$ \\
\hline Quercetin-3-O-glucoside & $2.33 \pm 0.21^{\mathrm{c}}$ & $0.63 \pm 0.10^{\mathrm{d}}$ & $3.36 \pm 0.12^{\mathrm{b}}$ & $0.60 \pm 0.09^{d}$ & $6.88 \pm 0.25^{\mathrm{a}}$ & $0.73 \pm 0.12^{\mathrm{d}}$ \\
\hline Quercetin-3-O-rutinoside & $33.37 \pm 1.88^{b}$ & $2.15 \pm 0.14^{\mathrm{d}}$ & $24.93 \pm 3.32^{c}$ & $2.03 \pm 0.14^{\mathrm{d}}$ & $49.77 \pm 5.24^{\mathrm{a}}$ & $2.49 \pm 0.17^{\mathrm{d}}$ \\
\hline Kaempferol-3-O-glucoside & $10.19 \pm 1.27^{\mathrm{b}}$ & $2.54 \pm 0.13^{\mathrm{d}}$ & $6.49 \pm 0.34^{\mathrm{c}}$ & $2.39 \pm 0.12^{\mathrm{d}}$ & $18.82 \pm 1.28^{\mathrm{a}}$ & $2.93 \pm 0.15^{\mathrm{d}}$ \\
\hline Myricetin & $5.08 \pm 0.16^{\mathrm{a}}$ & $1.83 \pm 0.17^{\mathrm{d}}$ & $2.30 \pm 0.14^{\mathrm{c}}$ & $1.73 \pm 0.16^{\mathrm{d}}$ & $3.71 \pm 0.18^{\mathrm{b}}$ & $2.12 \pm 0.19^{\mathrm{c}, \mathrm{d}}$ \\
\hline Quercetin & $3.23 \pm 0.13^{\mathrm{b}}$ & $1.79 \pm 0.24^{\mathrm{c}, \mathrm{d}}$ & $1.25 \pm 0.03^{\mathrm{d}}$ & $1.69 \pm 0.23^{\mathrm{c}, \mathrm{d}}$ & $4.82 \pm 0.16^{\mathrm{a}}$ & $2.06 \pm 0.28^{c}$ \\
\hline Total flavonols & $58.15 \pm 1.31^{\mathrm{b}}$ & $10.01 \pm 0.32^{\mathrm{c}}$ & $42.54 \pm 4.18^{\mathrm{b}}$ & $9.43 \pm 0.30^{\mathrm{c}}$ & $86.84 \pm 4.22^{\mathrm{a}}$ & $11.55 \pm 0.36^{\mathrm{c}}$ \\
\hline Piceatannol & $0.26 \pm 0.02^{\mathrm{b}}$ & $0.08 \pm 0.01^{\mathrm{c}}$ & $0.20 \pm 0.01^{b}$ & $0.08 \pm 0.01^{\mathrm{c}}$ & $0.57 \pm 0.04^{\mathrm{a}}$ & $0.27 \pm 0.03^{\mathrm{b}}$ \\
\hline trans-Resveratrol & $4.85 \pm 1.03^{\mathrm{a}}$ & $0.84 \pm 0.06^{\mathrm{d}}$ & $2.10 \pm 0.15^{\mathrm{c}}$ & $0.79 \pm 0.08^{\mathrm{d}}$ & $3.37 \pm 0.25^{\mathrm{b}}$ & $0.82 \pm 0.06^{\mathrm{d}}$ \\
\hline Total $E$-stilbenes & $5.12 \pm 1.05^{\mathrm{a}}$ & $0.92 \pm 0.07^{\mathrm{c}}$ & $2.30 \pm 0.16^{\mathrm{b}}$ & $0.87 \pm 0.09^{c}$ & $3.94 \pm 0.29^{\mathrm{a}}$ & $1.09 \pm 0.09^{\mathrm{b}, \mathrm{c}}$ \\
\hline Total phenolic compounds (TPC) & $513.02 \pm 20.02^{\mathrm{a}}$ & $80.34 \pm 4.18^{\mathrm{c.d}}$ & $294.87 \pm 11.47^{\mathrm{b}}$ & $82.57 \pm 3.68^{c . d}$ & $245.31 \pm 12.02^{\mathrm{b}}$ & $140.71 \pm 5.23^{\mathrm{c}}$ \\
\hline
\end{tabular}

WR: white rum; CMW/CMM: carbonic maceration wine/must; AW/AM: aged wine/must; HEW/HEM: high expression wine/must. Results are expressed in $\mu \mathrm{g} \mathrm{mL} \mathrm{m}^{-1}$.

the wines and musts $(p<0.05)$, followed by delphinidin-3-Oglucoside and petunidin-3-O-glucoside which also highlighted from the rest of the anthocyanins. The most abundant hydroxycinnamic acid derivatives were caftaric acid and coutaric acid, mainly found in the wines. On the contrary, $p$-coumaric acid and fertaric acid were minor compounds in the wines and undetectable in the musts. Moreover, quercetin-3-O-rutinoside and kaempferol-3-O-glucoside were identified as the major flavonols. Finally, the major stilbene was trans-resveratrol, both in the wines and musts.

\section{Qualitative analysis of isoprostanes in urine from healthy volunteers}

The qualitative profile of the IsoPs analyzed in this study is shown in Table $4 . \mathrm{F}_{2}$-IsoPs are reliable oxidative stress markers and they are considered gold standard markers by the European Food Safety Authority (EFSA). ${ }^{3,5}$ IsoPs found in every $48 \mathrm{~h}$ urine sample for the whole treatment are as follows:

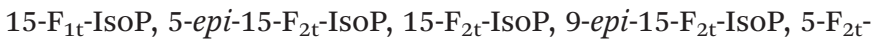
IsoP, $5-$ epi-5- $\mathrm{F}_{2 \mathrm{t}}-\mathrm{IsoP}$, ent-15-epi-15- $\mathrm{F}_{2 \mathrm{t}}-\mathrm{IsoP}$, ent- $\mathrm{PGF}_{2 \alpha}, 15-\mathrm{E}_{1 \mathrm{t}^{-}}$

Table 4 Isoprostane content in urine measured after the different treatments

\begin{tabular}{|c|c|c|c|c|c|c|c|c|}
\hline & Control & WR & CMW & CMM & AW & $\mathrm{AM}$ & HEW & HEM \\
\hline $15-\mathrm{F}_{1 \mathrm{t}}$-IsoP & $0.79 \pm 0.09$ & $0.70 \pm 0.20$ & $0.34 \pm 0.09$ & $0.59 \pm 0.15$ & $0.23 \pm 0.03$ & $0.65 \pm 0.12$ & $0.39 \pm 0.06$ & $0.62 \pm 0.09$ \\
\hline 5-epi-15- $\mathrm{F}_{2 \mathrm{t}}$-IsoP & $4.82 \pm 1.70$ & $4.36 \pm 1.17$ & $2.30 \pm 0.60$ & $4.72 \pm 1.03$ & $2.42 \pm 0.61$ & $5.36 \pm 0.89$ & $2.05 \pm 0.42$ & $4.39 \pm 0.9$ \\
\hline $15-\mathrm{F}_{2 \mathrm{t}}-\mathrm{IsoP}$ & $2.95 \pm 0.52$ & $2.66 \pm 0.37$ & $1.69 \pm 0.41$ & $2.21 \pm 0.58$ & $1.72 \pm 0.29$ & $3.46 \pm 0.58$ & $1.55 \pm 0.28$ & $2.84 \pm 0.39$ \\
\hline 9-epi-15- $\mathrm{F}_{2 \mathrm{t}}$-IsoP & $6.93 \pm 1.55$ & $5.97 \pm 1.84$ & $4.00 \pm 1.07$ & $6.34 \pm 0.88$ & $2.02 \pm 0.38$ & $4.15 \pm 0.70$ & $2.23 \pm 0.40$ & $3.47 \pm 0.50$ \\
\hline $5-\mathrm{F}_{2 \mathrm{t}}-\mathrm{IsOP}$ & $15.55 \pm 3.30$ & $14.07 \pm 4.07$ & $10.36 \pm 2.68$ & $14.33 \pm 3.33$ & $16.41 \pm 2.39$ & $16.34 \pm 2.88$ & $10.14 \pm 2.85$ & $15.93 \pm 2.43$ \\
\hline 5-epi-5- $\mathrm{F}_{2 \mathrm{t}}$-IsoP & $33.05 \pm 7.82$ & $32.54 \pm 9.59$ & $22.93 \pm 5.63$ & $27.83 \pm 6.57$ & $23.63 \pm 5.68$ & $32.33 \pm 6.44$ & $20.43 \pm 4.40$ & $26.70 \pm 4.46$ \\
\hline ent-15-epi-15- $\mathrm{F}_{2 \mathrm{t}}$-IsoP & $21.96 \pm 5.26$ & $17.70 \pm 5.23$ & $10.62 \pm 2.85$ & $17.37 \pm 3.35$ & $7.83 \pm 1.72$ & $14.30 \pm 2.24$ & $7.56 \pm 1.68$ & $14.57 \pm 2.73$ \\
\hline$e n t-\mathrm{PGF}_{2 \alpha}$ & $1.96 \pm 0.45$ & $1.70 \pm 0.30$ & $1.24 \pm 0.32$ & $1.64 \pm 0.46$ & $0.65 \pm 0.18$ & $1.17 \pm 0.13$ & $0.53 \pm 0.12$ & $1.01 \pm 0.17$ \\
\hline $15-\mathrm{E}_{1 \mathrm{t}}$-IsoP & $11.25 \pm 1.58$ & $9.39 \pm 1.43$ & $8.35 \pm 1.96$ & $9.13 \pm 1.32$ & $7.43 \pm 1.53$ & $12.42 \pm 1.78$ & $7.15 \pm 1.13$ & $12.66 \pm 1.57$ \\
\hline $8-\mathrm{F}_{3 \mathrm{t}}$-IsoP & $2.61 \pm 0.54$ & $2.40 \pm 0.30$ & $1.32 \pm 0.34$ & $2.24 \pm 0.44$ & $1.48 \pm 0.30$ & $2.82 \pm 0.39$ & $1.19 \pm 0.13$ & $2.25 \pm 0.36$ \\
\hline 2,3-Dinor-15- $\mathrm{F}_{2 \mathrm{t}}$-IsoP & $88.89 \pm 20.74$ & $59.35 \pm 14.21$ & $35.81 \pm 8.94$ & $64.52 \pm 18.94$ & $52.24 \pm 6.87$ & $31.51 \pm 5.32$ & $29.24 \pm 4.52$ & $52.32 \pm 7.96$ \\
\hline 2,3-Dinor-15-epi-15- $\mathrm{F}_{2 \mathrm{t}}$-IsoP & $7.71 \pm 1.89$ & $7.37 \pm 2.06$ & $3.47 \pm 0.87$ & $6.46 \pm 1.59$ & $5.15 \pm 0.72$ & $5.15 \pm 0.88$ & $5.15 \pm 0.47$ & $5.15 \pm 0.77$ \\
\hline
\end{tabular}

Means are expressed in $\mu \mathrm{g} 24 \mathrm{~h}^{-1}$. WR: white rum; CMW/CMM: carbonic maceration wine/must; AW/AM: aged wine/must; HEW/HEM: high expression wine/must. 
IsoP, 8- F $_{3 \mathrm{t}}$-IsoP, 2,3-dinor-15- $\mathrm{F}_{2 \mathrm{t}}$-IsoP, and 2,3-dinor-15-epi-15$\mathrm{F}_{2 \mathrm{t}}$-IsoP. These markers helped us to describe the protection grade against systemic oxidative stress (in vivo antioxidant capacity) after the intake of the different musts and wines by healthy volunteers included in this study. Other IsoPs were not found in any urine sample: $15-$ keto-15- $\mathrm{F}_{2 \mathrm{t}}$-IsoP, 15-keto-15- $\mathrm{E}_{2 \mathrm{t}^{-}}$ IsoP, 15-epi-15- $\mathrm{E}_{2 \mathrm{t}}$-IsoP, and 8-epi-8- $\mathrm{F}_{3 \mathrm{t}}$-IsoP.

\section{Quantitative analysis of isoprostanes after the intake of red wines by healthy volunteers}

Total urinary IsoPs are shown in Fig. 2. As can be observed, the control period largely exhibited the major total IsoP content of all stages $\left(198.46 \pm 45.43 \mu \mathrm{g} 24 \mathrm{~h}^{-1}\right)$. Statistically, minor urinary concentrations of total IsoPs were found after the intake of the three assayed wines $(p<0.05)$. Therefore, the IsoP content decreased until $102.43 \pm 25.77 \mu \mathrm{g} 24 \mathrm{~h}^{-1}, 98.38 \pm$ $20.72 \mu \mathrm{g} 24 \mathrm{~h}^{-1}$, and $85.21 \pm 16.48 \mu \mathrm{g} 24 \mathrm{~h}^{-1}$ upon the administration of a cup of carbonic maceration wine (CMW), aged wine (AW), and high expression wine (HEW), respectively.

The administration of an ethanol control - marked by the intake of white rum (WR) - also presented a minor concentration of total IsoPs $\left(158.22 \pm 40.75 \mu \mathrm{g} 24 \mathrm{~h}^{-1}\right)$ compared to that in the control period. However, contrary to the intake of the wines, the differences were not statistically significant $(p>0.05)$.

A similar trend was found after the intake of the three primary musts assayed in the current trial. All three musts led to a minor total IsoP content compared with that in the control period. However, they did not reach the lowest total IsoP concentration, noticeable for the wine treatments $(p>$ 0.05). So, the intake of the primary musts for carbonic maceration wine (CMM), aged wine (AM) and high expression wine (HEM) led to $157.39 \pm 36.62 \mu \mathrm{g} 24 \mathrm{~h}^{-1}, 150.81 \pm 25.36 \mu \mathrm{g}$ $24 \mathrm{~h}^{-1}$ and $141.85 \pm 22.41 \mu \mathrm{g} 24 \mathrm{~h}^{-1}$ respectively.

Therefore, ethanol intake and must treatments showed antioxidant protection observed by total IsoP excretion. However,

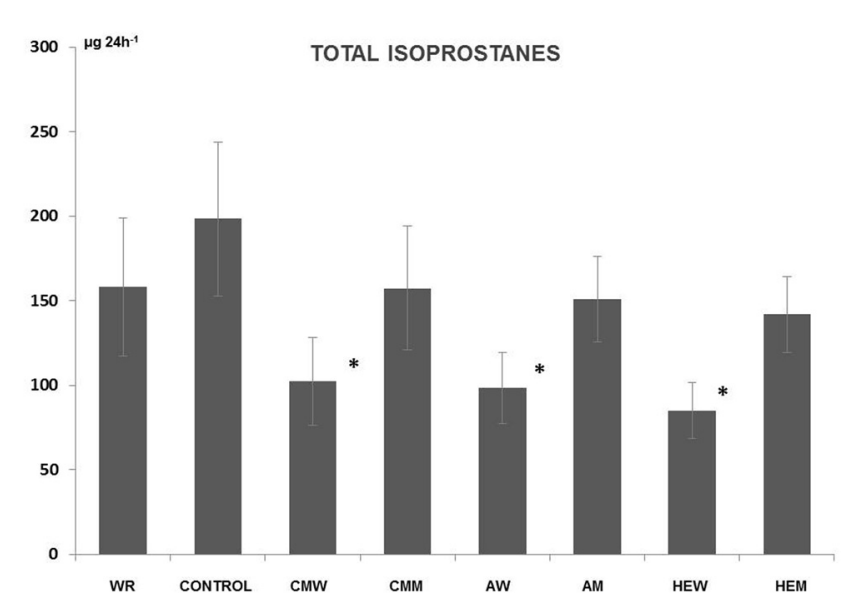

Fig. 2 Total IsoPs found in urine. Means are expressed in $\mu \mathrm{g} 24 \mathrm{~h}^{-1}$. WR: white rum; CMW/CMM: carbonic maceration wine/must; AW/AM: aged wine/must; HEW/HEM: high expression wine/must. *Represents statistical differences. they exhibited minor antioxidant protection compared to the treatments with their respective wines.

The disparity of individual IsoPs between the control stage and other periods has also been studied. A total of 12 IsoPs were identified in urine (Table 4 ). The most abundant compounds were 2,3-dinor- $15-\mathrm{F}_{2 \mathrm{t}}$-IsoP, 5-epi-5- $\mathrm{F}_{2 \mathrm{t}}$-IsoP and ent-15epi-15- $\mathrm{F}_{2 \mathrm{t}}$-IsoP. As expected, the trend followed by total IsoPs was concomitant but more deeply marked than that of the individual IsoP content.

Largely, the higher content of every individual IsoP was mainly found after the control period. However, different trends could be observed in the different IsoPs. Two IsoPs were found to have similar urinary contents over the whole

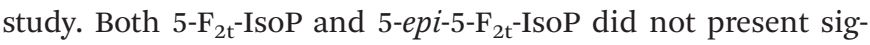
nificant differences after any of the treatments $(p>0.05)$. The content of 2,3-dinor- $15-\mathrm{F}_{2 \mathrm{t}}$-IsoP in urine at baseline was 27.40 $\pm 6.24 \mu \mathrm{g} 24 \mathrm{~h}^{-1}$, presenting a statistical decrease after the intake of every beverage of the study $(p<0.05)$. After the control period, $15-\mathrm{F}_{1 \mathrm{t}}$-IsoP $\left(0.79 \pm 0.09 \mu \mathrm{g} 24 \mathrm{~h}^{-1}\right)$, ent-15-epi$15 \mathrm{~F}_{2 \mathrm{t}}$-IsoP $\left(21.96 \pm 5.96 \mu \mathrm{g} 24 \mathrm{~h}^{-1}\right), 2,3$-dinor-15- $\mathrm{F}_{2 \mathrm{t}}$-IsoP (88.89 $\pm 20.74 \mu \mathrm{g} 24 \mathrm{~h}^{-1}$ ) and 2,3-dinor-15-epi-15- $\mathrm{F}_{2 \mathrm{t}}$-IsoP (7.71 \pm $1.89 \mu \mathrm{g} 24 \mathrm{~h}^{-1}$ ) were detected at higher amounts than after the intake of CMW, AW and HEW $(p<0.01)$. In the control period, the 9-epi-15- $\mathrm{F}_{2 \mathrm{t}}$-IsoP and ent-PGF $\mathrm{PG}_{2 \alpha}$ contents were $6.93 \pm$ $1.55 \mu \mathrm{g} 24 \mathrm{~h}^{-1}$ and $1.96 \pm 0.45 \mu \mathrm{g} 24 \mathrm{~h}^{-1}$, respectively, but after the intake of AW and HEW, these decreased significantly $(p<$ $0.05)$. As reflected by the results, the wine treatments were able to considerably reduce the IsoP content marked by the control period. In fact, only 15-epi-15- $\mathrm{F}_{2 \mathrm{t}}$-IsoP was found in a minor concentration after the ingestion of AM and HEM compared to the control period $(p<0.05)$ (Table 6).

The differences between the treatments with wines and their main musts were also studied. The intake of AW led to a smaller urinary content of $15-\mathrm{F}_{1 \mathrm{t}}$-IsoP, 15-epi-15- $\mathrm{F}_{2 \mathrm{t}}$-IsoP, $15-\mathrm{E}_{1 \mathrm{t}}$-IsoP, $8-\mathrm{F}_{3 \mathrm{t}}$-IsoP and $15-\mathrm{F}_{2 \mathrm{t}}$-IsoP than the intake of $\mathrm{AM}$ $(p<0.05)$. The intake of HEW also reported a lower amount of some IsoPs than its corresponding must. $15-\mathrm{E}_{1 \mathrm{t}}-\mathrm{IsoP}, 8-\mathrm{F}_{3 \mathrm{t}}$-IsoP and $15-\mathrm{F}_{2 \mathrm{t}}$-IsoP were also found in a lower quantity after the intake of HEW compared to the intake of HEM $(p<0.05)$.

Finally, WR intake only caused a significant reduction in the case of 2,3-dinor-15- $\mathrm{F}_{2 \mathrm{t}}$-IsoP. In fact, after the intake of CMW and AW, $15-\mathrm{F}_{1 \mathrm{t}}$-IsoP showed significantly smaller urinary values than that after the intake of $\mathrm{WR}(p<0.05)$. The same trends were found after the intake of AW and HEW when quantifying 9-epi-15- $\mathrm{F}_{2 \mathrm{t}}$-IsoP, ent-15- $\mathrm{F}_{2 \mathrm{t}}$-IsoP, ent-PGF $\mathrm{P}_{2 \alpha}$ and 2,3dinor-15- $\mathrm{F}_{2 \mathrm{t}}$-IsoP. The same behavior was found for $8-\mathrm{F}_{3 \mathrm{t}}$-IsoP after the intake of CMW and HEW, and for 2,3-dinor-15-epi-15$\mathrm{F}_{2 \mathrm{t}}$-IsoP after the intake of CMW, AW and HEW.

\section{Qualitative analysis of prostaglandins after the intake of red wines by healthy volunteers}

In order to clarify the health effects of the different treatments, PG series were divided into groups, according to their main precursor in the corresponding physiological pathway (Table 5). Therefore, the groups were defined as shown in Table 6. The individual PGs found in the urine samples were: 
Table 5 Prostaglandin content in urine measured after the different treatments

\begin{tabular}{|c|c|c|c|c|c|c|c|c|}
\hline \multicolumn{9}{|l|}{ PGs SERIE D } \\
\hline $11-\beta-\mathrm{PGF}_{2 \alpha}$ & $2.03 \pm 0.38$ & $2.42 \pm 0.62$ & $1.85 \pm 0.51$ & $2.12 \pm 0.44$ & $1.82 \pm 0.41$ & $2.61 \pm 0.57$ & $1.77 \pm 0.38$ & $2.24 \pm 0.44$ \\
\hline Tetranor-PGDM & $40.16 \pm 9.44$ & $41.88 \pm 9.61$ & $35.05 \pm 7.35$ & $34.80 \pm 5.82$ & $34.12 \pm 7.17$ & $34.23 \pm 7.59$ & $24.59 \pm 6.27$ & $23.22 \pm 4.39$ \\
\hline 2,3 -Dinor-11- $\beta$-PGF 2 & $100.95 \pm 22.09$ & $56.40 \pm 10.27$ & $32.92 \pm 6.71$ & $37.09 \pm 5.77$ & $39.64 \pm 7.20$ & $44.21 \pm 8.64$ & $26.53 \pm 3.86$ & $29.22 \pm 7.04$ \\
\hline Tetranor-PGDM lactone & $46.16 \pm 11.86$ & $45.17 \pm 12.50$ & $33.60 \pm 8.51$ & $25.81 \pm 7.01$ & $39.67 \pm 7.44$ & $39.41 \pm 6.82$ & $35.24 \pm 6.55$ & $47.80 \pm 10.19$ \\
\hline Tetranor-PGJM & $0.88 \pm 0.19$ & $1.48 \pm 0.34$ & $0.86 \pm 0.16$ & $0.90 \pm 0.18$ & $0.64 \pm 0.12$ & $1.13 \pm 0.21$ & $0.75 \pm 0.18$ & $0.89 \pm 0.11$ \\
\hline Tetranor-PGEM & $9.01 \pm 2.53$ & $8.50 \pm$ & $10.10 \pm$ & $8.89 \pm 2.44$ & $16.11 \pm 3.39$ & $23.17 \pm 4.05$ & $7.75=$ & $10.26=$ \\
\hline 20-OH-PGE 2 & $10.56 \pm 1.71$ & $14.20 \pm 3.62$ & $14.58 \pm 3.84$ & $11.10 \pm 2.66$ & $11.25 \pm 2.38$ & $12.42 \pm 4.05$ & $11.52 \pm 2.56$ & $13.39 \pm 3.67$ \\
\hline $\mathrm{PGE}_{2}$ & $0.81 \pm 0.21$ & $1.11 \pm 0.29$ & $0.96 \pm 0.25$ & $0.82 \pm 0.17$ & $0.59 \pm 0.14$ & $0.96 \pm 0.20$ & $0.75 \pm 0.15$ & $0.88 \pm 0.17$ \\
\hline \multicolumn{9}{|l|}{ PGs SERIE F } \\
\hline $20-\mathrm{OH}-\mathrm{PGF}_{2 \alpha}$ & $36.91 \pm 10.10$ & $26.45 \pm 3.62$ & $44.29 \pm 16.6$ & $52.94 \pm 15.44$ & $27.13 \pm 7.84$ & $41.11 \pm 15.53$ & $27.45 \pm 8.60$ & $40.29 \pm 11.25$ \\
\hline $19(R)-\mathrm{OH}-\mathrm{PGF}_{2 \alpha}$ & $54.60 \pm 11.87$ & $45.71 \pm 7.68$ & $57.92 \pm 13.25$ & $48.19 \pm 2.28$ & $55.45 \pm 10.88$ & $68.00 \pm 16.80$ & $45.09 \pm 8.6$ & $44.58 \pm 7.48$ \\
\hline
\end{tabular}

Means are expressed in $\mu \mathrm{g} 24 \mathrm{~h}^{-1}$. WR: white rum; CMW/CMM: carbonic maceration wine/must; AW/AM: aged wine/must; HEW/HEM: high expression wine/must.

Table 6 Determination coefficients derived from the study of simple regression and multiple regression of the urinary excretion of total IsoPs and $\mathrm{PGE}_{1}$

\begin{tabular}{lll}
\hline & Total IsoPs & PGE $_{1}$ \\
\hline Simple regression $\left(\mathbf{R}^{2}\right)$ & & \\
MEL & 0.060 & 0.538 \\
OHTyr & 0.334 & 0.139 \\
HV-Acid & 0.029 & 0.062 \\
HV-Alc & 0.254 & 0.390 \\
TPC & 0.101 & 0.407 \\
& & \\
Multiple regression & & \\
$\mathrm{R}^{2}$ Tot. & 0.424 & 0.609 \\
$\mathrm{R}^{2}$ Select. & 0.405 (OHTyr) & 0.599 (MEL, OHTyr)
\end{tabular}

MEL: melatonin; OHTyr: hydroxytyrosol; HV-Acid: homovanillic acid; HV-Alc: homovanillic alcohol; TPC: total phenolic compounds. $\mathrm{R}^{2}$ Tot.: coefficient of regression which expresses the statistical significance of all the compounds studied with respect to each biomarker. $\mathrm{R}^{2}$ Select.: coefficient of determination of compounds selected by the statistical robustness model. All these values have to be treated as \% of influence on the final concentration.

for PG-D series, 11- $\beta-\mathrm{PGF}_{2 \alpha}$, PGDM, Tetranor PGDM, 2,3-dinor$11-\beta-\mathrm{PGF}_{2}$, tetranor-PGDM lactone and tetranor PGJM; for PG-E series, tetranor PGAM, tetranor PGEM, 20-OH-PGE ${ }_{2}$ and $\mathrm{PGE}_{2}$; and for PG-F series, 20-OH-PGF $2 \alpha, 19(R)-\mathrm{OH}-\mathrm{PGF}_{2 \alpha}$, and tetranor PGFM. Finally, PGs proceeding from dihomo$\gamma$-linolenic acid and eicosapentaenoic acid were represented by $\mathrm{PGF}_{1 \alpha}, \mathrm{PGE}_{1}$ and 17-trans-PGF $3 \alpha$.

\section{Quantitative analysis of prostaglandins in $24 \mathrm{~h}$ urine from} healthy volunteers

Regarding total PG content, Fig. 3 and 4 present the variation of the different PG families over the whole clinical trial. Total PG-D series presented a dramatic decrease in their concen-
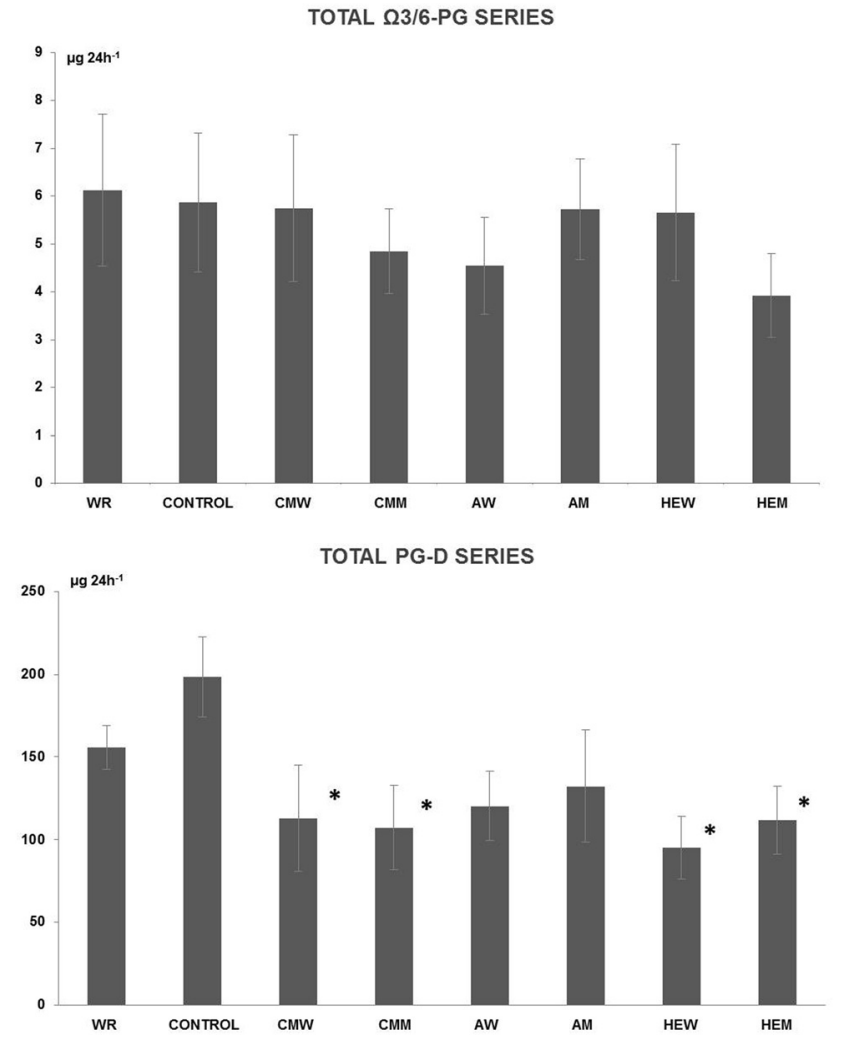

Fig. 3 Total PG-H and PG-G found in urine. Means are expressed in $\mu \mathrm{g}$ $24 \mathrm{~h}^{-1}$. WR: white rum; CMW/CMM: carbonic maceration wine/must; AW/AM: aged wine/must; HEW/HEM: high expression wine/must. *Represents statistical differences.

tration after the intake of the different beverages compared with the control period (Fig. 3). The decrease in the urinary excretion of PGs was not common to all PG series. In fact, total 

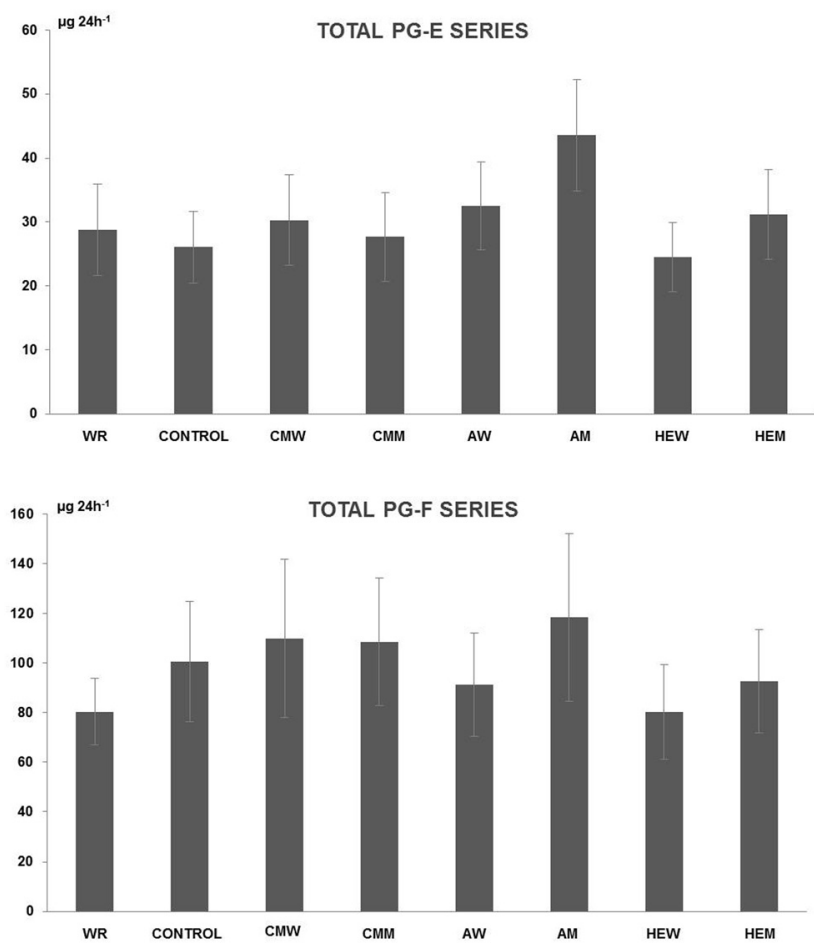

Fig. 4 Total PG-E and PG-F found in urine. Means are expressed in $\mu \mathrm{g}$ $24 \mathrm{~h}^{-1}$. WR: white rum; CMW/CMM: carbonic maceration wine/must; AW/AM: aged wine/must; HEW/HEM: high expression wine/must.

PG-E series and total PG-F series did not show a uniform decrease pattern. In contrast, the contents of urinary PG-E and PG-F series were smaller after the control period than those after the intake of all beverages except for HEM (Fig. 4). Total $\Omega 3 / 6$-PG series provided a uniform pattern among all the treatments (Fig. 3). Nonetheless, only the urinary content of total PG-D series showed significant statistical variation. After the intake of CMW and HEW and their corresponding musts (CMM and HEM), the urinary content of total PG-D series was smaller during these treatments than that at the baseline $(p<0.05)$.

The individual content of the different prostaglandin series was also studied (Table 6). The urinary excretion of PGs did not vary widely. In fact, only the urinary content of 2,3-dinor$11 \beta-\mathrm{PGF}_{2}$, tetranor PGEM, $\mathrm{PGE}_{1}$ and 17 -trans-PGF $\mathrm{P}_{3 \alpha}$ presented statistically significant modifications. After the control period, 2,3-dinor-11- $\beta$ - $\mathrm{PGF}_{2}$ showed a higher urinary content (100.95 \pm $22.09 \mu \mathrm{g} 24 \mathrm{~h}^{-1}$ ) than after the intake of the three musts and their finished wines $(p<0.05)$. Therefore, the urinary content of 2,3-dinor-11- $\beta$ - $\mathrm{PGF}_{2}$ after the intake of musts was $37.09 \pm$ $5.77 \mu \mathrm{g} 24 \mathrm{~h}^{-1}$ for CMM, $44.21 \pm 8.64 \mu \mathrm{g} 24 \mathrm{~h}^{-1}$ for AM and $29.22 \pm 7.04 \mu \mathrm{g} 24 \mathrm{~h}^{-1}$ for HEM. Finally, the content of 2,3dinor-11- $\beta-\mathrm{PGF}_{2}$ after the intake of the wines was $32.92 \pm$ $6.71 \mu \mathrm{g} 24 \mathrm{~h}^{-1}$ for CMW, $35.68 \pm 7.20 \mu \mathrm{g} 24 \mathrm{~h}^{-1}$ for AW and $26.53 \pm 3.86 \mu \mathrm{g} 24 \mathrm{~h}^{-1}$ for HEW.

Two PGs - $\mathrm{PGE}_{1}$ and 17-trans- $\mathrm{PGF}_{3 \alpha}$ - from the enzymatic oxidation of $\Omega 3 / 6$ fatty acids were the last individual PGs which showed a statistical variation with respect to the control period. The intake of all three wines was able to increase the urinary content of $\mathrm{PGE}_{1}(p<0.05)$, with respect to the control period $\left(0.24 \pm 0.11 \mu \mathrm{g} 24 \mathrm{~h}^{-1}\right)$. After the intake of CMW, the $\mathrm{PGE}_{1}$ content was $2.10 \pm 0.58 \mu \mathrm{g} 24 \mathrm{~h}^{-1}$ and it was $1.23 \pm$ $0.25 \mu \mathrm{g} 24 \mathrm{~h}^{-1}$ and $1.44 \pm 0.52 \mu \mathrm{g} 24 \mathrm{~h}^{-1}$ after the intake of AW and HEW, respectively. 17-trans-PGF ${ }_{3 \alpha}$ seemed to be modified by the intake of HEM and its corresponding wine, HEW. After the control period, the content of 17-trans-PGF Pa $_{3 \alpha}$ was $3.26 \pm$ $0.81 \mu \mathrm{g} 24 \mathrm{~h}^{-1}$. However, after the intake of HEM, its content was $1.37 \pm 0.26 \mu \mathrm{g} 24 \mathrm{~h}^{-1}$, achieving similar results for HEW $\left(1.33 \pm 0.30 \mu \mathrm{g} 24 \mathrm{~h}^{-1}\right)$.

Finally, despite some individual PGs showing variations (cited above) after the intake of the beverages, no variations related to the intake of WR were found in any of the cases.

\section{Discussion}

Moderate consumption of red wine has been related to the cardioprotective and antioxidant benefits for human beings, mainly attributed to polyphenols. ${ }^{18}$ However, the scientific literature has widely shown their poor absorption at the intestinal level, ${ }^{35-37}$ limiting their activity in vivo. However, anthocyanins, which are the most important polyphenol in wines, are directly absorbed in the intestine, exerting the major benefits. $^{38}$ In the present work, the individual intake of hydroxytyrosol and total polyphenols - not including colon derivatives (only hydroxytyrosol microflora metabolites) - has been related to the formation of lipid peroxidation products and the enzymatic formation of oxylipins. Moreover, other anti-inflammatory compounds such as phytoprostanes are well absorbed in the intestine, showing health benefits despite colonic metabolites not being reported yet. ${ }^{4,39}$

Therefore, this preliminary intervention may help to understand the role of certain wine compounds in the oxidation of AA and the formation of enzymatic oxylipins.

\section{Isoprostanes after the intake of wine and must by healthy volunteers}

The urinary content of IsoPs decreased after the ingestion of the three types of wine. Red wine has shown in vivo protection against oxidative stress (related to antioxidant capacity). However, this was mainly attributed to its content of bioactive compounds and their antioxidant capacity. ${ }^{40-42}$ Not only wines, but also the intake of musts proved to be able to reduce the excretion of IsoPs. Finally, the oral administration of ethanol - shown as WR in the figures and tables - also reduced the urinary excretion of IsoPs, emphasizing the in vivo antioxidant capacity of ethanol.

However, the amount of bioactive compounds present in the wine is greater and more varied than that observed in their musts. Moreover, the intake of wine leads to the ingestion of ethanol (similar amount to WR). Red wines provide a varied amount of bioactive compounds; the intake of CMW provides a greater amount of MEL, while the intake of AW and HEW provides a higher content of OHTyr. Given the antioxidant 
capacity of both compounds, the intake of every wine led to an increase in the protection against oxidative stress by the accumulation of antioxidant compounds. Due to the greater amount of bioactive compounds and the presence of ethanol, red wine intake decreased the urinary excretion of IsoPs more than the intake of the primary musts (without ethanol) and the intake of WR (non-bioactive compounds).

The characterization of the samples allowed the establishment of a relationship between bioactive compounds and the urinary excretion of lipid peroxidation markers, and vascular function and inflammation markers. The total urinary excretion of IsoPs was individually associated with the different bioactive compounds and TPC of the samples, as shown in Table 6. OHTyr has shown its antioxidant capacity in vivo. ${ }^{19,43}$ Indeed, the simple regression analysis showed an inverse relationship between the content of OHTyr of wines and musts, and the urinary excretion of IsoPs. OHTyr is responsible for $33.4 \%$ of the observed change in the excretion of IsoPs. Moreover, the HV-Alc administration was also inversely related to the urinary excretion of IsoPs $(25.4 \%$ of the effect). Although less marked, TPC intake was also shown to be inversely related to IsoP excretion, accounting for $10.1 \%$ of the change observed. Finally, the oral administration of MEL and HV-Acid was also inversely correlated with the total IsoP excretion, accounting for $6 \%$ and $2.9 \%$ of the observed changes, respectively.

Finally, multiple regression analysis showed that $42.4 \%$ of the change in the urinary excretion of IsoPs can be explained by the combined intake of the different compounds present in wine and must. However (as shown in Table 6), when analyzing the data simultaneously, the content of OHTyr seems to be the key factor producing the observed changes in the excretion of IsoPs. OHTyr was responsible for $40.5 \%$ of the observed variations in the IsoP urinary excretion, when it was simultaneously compared with the other compounds.

\section{Prostaglandins after the intake of wine and must by healthy volunteers}

The biological functions of PGs have been extensively studied. Depending on the studied family, a wide variety of actions can be attributed. ${ }^{44}$ PG functions depend on the family to which they belong. PG-D series can exert both vasoconstrictor effects and vasodilator effects in the organism. ${ }^{10,44-48}$ PG-I series could not be quantified in urine because they were not detected during this study; however, they are capable of exerting platelet, antiplatelet and vasodilator effects, with the consequent prevention of cardiovascular diseases. ${ }^{49,50}$ Another family of PGs, PG-E series, demonstrated neuroprotective capacity, as well as pro-inflammatory and anti-inflammatory actions. ${ }^{51-53}$ Finally, PG-F-series could be partly responsible for the pro-inflammatory effects of PGs. ${ }^{44}$

Urinary excretion of the PG-D family was affected to a greater extent than that of the PG-H family. The intake of three wines and three musts caused a decrease in the excretion of the PGs of series D (Fig. 3). Particularly, 2,3-dinor-11- $\beta-\mathrm{PGF}_{2 \alpha}$ decreased significantly $(p<0.01)$ within the PG-D family
(Table 5). The biological activity of 2,3-dinor-11- $\beta-\mathrm{PGF}_{2 \alpha}$ is very similar to that of $11-\beta-\mathrm{PGF}_{2 \alpha}$, increasing bronchoconstriction $^{54,55}$ and inhibiting adipose differentiation. ${ }^{56,57}$

The levels of the PG-E family in urine remained stable throughout the study except after the ingestion of AM (Fig. 4), resulting in a particularly important increase in the excretion of tetranor PGEM (Table 5). The biological action of tetranor PGEM has not been investigated enough, but it is a representative marker of the synthesis of $\mathrm{PGE}_{1}$ and $\mathrm{PGE}_{2}$. $\mathrm{PGE}_{1}$ exerts vasodilator effects, while the effects of $\mathrm{PGE}_{2}$ are variable, and depending on the receiver, it can exert vasoconstriction or vasodilatation, as well as bronchoconstriction and bronchodilator effects. ${ }^{58}$ Therefore, an increase in the excretion of tetranor PGEM can be representative of a vasodilator effect exerted by $\mathrm{PGE}_{1}$ and $\mathrm{PGE}_{2}$.

From the two remaining PG families, PG-F levels remained constant $(p>0.05)$ in urine throughout the study (Fig. 4). However, the excretion of -the $\Omega 3 / 6-\mathrm{PG}$ series presented marked differences. After the intake of HEM, the levels of $\mathrm{PGF}_{1 \alpha}$ and 17-trans-PGF $\mathrm{PG}_{3 \alpha}$ in urine decreased considerably. Finally, the urinary excretion of $\mathrm{PGE}_{1}$ increased considerably after the ingestion of the three types of wine (Table 6). The biological activity of $\mathrm{PGE}_{1}$ is relevant, as already mentioned, acting as a vasodilator, and it may act as an important compound for the cardiovascular balance. ${ }^{59-61}$

The effects of PGs as individual compounds may be even more diverse. They can exert anti- or pro-inflammatory effects, depending upon the compound and the receptor, in addition to depending upon the tissue where the action occurs. ${ }^{44}$

Thus, the intake of red wines was able to decrease the urinary excretion of pro-inflammatory prostaglandin (acting as pro-aggregating compounds and vasoconstrictors) such as 2,3dinor-11- $\beta-\mathrm{PGF}_{2 \alpha}$. In turn, wine intake increased the excretion of another vasodilator prostaglandin, $\mathrm{PGE}_{1}$. These results strengthen the cardioprotective effects of red wine intake in particular and an ingredient of MD in general.

In response to these findings, statistical analysis was performed to describe the relationship of the bioactive compounds in red wine and musts and the actions described above. In this way, it was found that the relationship of PGs with bioactive compounds was widely distributed, and some relationships are noteworthy.

OHTyr intake also showed a relationship with the urinary excretion of some PGs. The specific PGs that were inversely related $(p<0.05)$ to the contents of OHTyr were $11-\beta-\mathrm{PGF}_{2 \alpha}$, tetranor PGJM, tetranor PGAM, 20-OH-PGF ${ }_{2 \alpha}$ and 17-trans-PGF ${ }_{3 \alpha}$.

Based on these results, statistical relationships were established in the same way as that used for studying the relationship with IsoPs. Thus, it was found that the ratio of PG with bioactive compounds was very irregular, and there is no pattern to define it. However, the statistical relationship of $\mathrm{PGE}_{1}$, which, as described above, can exert vasodilator capacity, ${ }^{59-61}$ with the different compounds present in wines and musts was noticeable (Table 6).

From simple regression, the urinary excretion of $\mathrm{PGE}_{1}$ was dependent on a $53.8 \%$ by the intake of MEL, $13.9 \%$ by OHTyr, 
$6.2 \%$ by HV-Acid, $39 \%$ by HV-Alc and $40.7 \%$ by TPC. In turn, the study of multiple regression showed that the observed variations in the excretion of $\mathrm{PGE}_{1}$ are dependent in a $60.9 \%$ by the whole of the compounds studied simultaneously. However, the intake of MEL and OHTyr was determinant, both being responsible for $59.9 \%$ of the observed increase in the excretion of PGE1.

The cardioprotective effects of $\mathrm{PGE}_{1}$, and the direct relationship found between the ingestion of bioactive compounds and their excretion in urine may be important in the understanding of the cardioprotective effects of red wine. On the other hand, the intake of musts and WR (providing bioactive compounds and ethanol, respectively) cannot provide the cardioprotective effects as provided by the intake of red wines (contributing ethanol and bioactive compounds) measured by urinary $\mathrm{PGE}_{1}$.

These results reinforce the findings of the previous publications, and exalt the role of red wine as a supporter of the beneficial actions of MD. Finally, it is apparent that the content of OHTyr and MEL is a key factor in the antioxidant protection of red wines. Furthermore, the cardioprotective capacity of red wine can be related to the increase of $\mathrm{PGE}_{1}$.

\section{Conclusions}

Wine treatments are more effective in reducing in vivo oxidative stress than the treatments with their corresponding musts and/or white rum (ethanol). Specifically, HEW showed to be the most effective wine reducing total IsoPs.

The capacity of wine and musts to decrease the concentration of IsoPs is statistically related to their content of OHTyr. Therefore, the wine showing a higher OHTyr concentration was able to provide a higher reduction of the oxidative status of the organism. To a small extent $(p>0.05)$, MEL was also related to the antioxidant protection of the treatments, so that the treatments which provided more MEL led to higher protection against oxidative stress.

Both alcohol and bioactive compounds seem to be partly responsible for the antioxidant capacity of the beverages. Red wines containing both bioactive compounds and alcohol became the best treatment for reducing the organism's oxidative status measured by total IsoPs $(p<0.05)$ compared to musts and alcohol. In fact, the correlation between the different bioactive compounds present in the three wines and the drop in total IsoPs is statistically significant. In contrast, alcohol and bioactive compounds separately are not enough to reduce lipid peroxidation. In addition, the intake of red wine led to cardioprotective effects by reducing the urinary excretion of the pro-inflammatory prostaglandin 2,3-dinor-11- $\beta-\mathrm{PGF}_{2 \alpha}$, besides increasing the vasodilator prostaglandin $\mathrm{PGE}_{1}$, mediated by the melatonin $(p<0.05)$ and hydroxytyrosol $(p<0.05)$ contents.

Therefore, MEL and OHTyr and their derivatives can be important compounds in wine and must for the reduction of oxidative injury. However, other compounds such as poly- phenol colon derivatives and newly discovered phytoprostanes may also be effective compounds for reducing oxidative damage. Moreover, chemical reactions that occur during the winemaking process (oxidation or polymerization) make the comparison between wine musts and wine more difficult, because the changes produced in their chemical and phenolic composition make the two beverages completely different from each other. ${ }^{18,30}$ Therefore, further studies will help to understand the effect of other bioactive compounds on reducing lipid peroxidation and prostaglandin formation.

\section{Author contribution}

Javier Marhuenda carried out the analytical processes and wrote and discussed the present paper. Sonia Medina supervised the analytical processes and developed the discussion of the paper. Pedro Martinez-Hernández and Simón Arina provided the beverages of the study and supervised the article. Pilar Zafrilla and Juana Mulero developed the randomized controlled trial. Hans Camille Oger, Jean-Marie Galano and Thierry Durand provided the markers for the study and helped with the review of the manuscript. Federico Ferreres helped with the experimental procedures linked to UHPLC-QqQ-MS/ MS. Ángel Gil-Izquierdo and Sonia Medina designed, supervised, and discussed this research work.

\section{Conflicts of interest}

The authors declare that there is no conflict of interest associated with this manuscript.

\section{Acknowledgements}

This work has been partially funded by the "Fundación Séneca de la Región de Murcia” Grupo de Excelencia 19900/GERM/15. The authors are grateful to UCAM for the support provided during the development of the assay for the study. Sonia Medina is grateful to the CICYT for a research contract (AGL2011-23690). Special thanks to David Walker for the revision and correction of English grammar.

\section{References}

1 E. Miller, A. Morel, L. Saso and J. Saluk, Isoprostanes and neuroprostanes as biomarkers of oxidative stress in neurodegenerative diseases, Oxid. Med. Cell. Longevity, 2014, 572491.

2 R. Imbusch and M. J. Mueller, Formation of isoprostane F2-like compounds (phytoprostanes F1) from $\alpha$-linolenic acid in plants, Free Radical Biol. Med., 2000, 28, 720-726.

3 S. Medina, R. Domínguez-Perles, J. I. Gil, F. Ferreres, C. García-Viguera, J. M. Martínez-Sanz and A. GilIzquierdo, A ultra-pressure liquid chromatography/triple 
quadrupole tandem mass spectrometry method for the analysis of 13 eicosanoids in human urine and quantitative 24 hours values in healthy volunteers in a controlled constant diet, Rapid Commun. Mass Spectrom., 2012, 26, 12491257.

4 J. Marhuenda, S. Medina, A. Díaz-Castro, P. MartínezHernández, S. Arina, P. Zafrilla, J. Mulero, C. Oger, J.-M. Galano, T. Durand, F. Ferreres and Á. Gil-Izquierdo, Dependency of Phytoprostane Fingerprints of Must and Wine on Viticulture and Enological Processes, J. Agric. Food Chem., 2015, 63, 9022-9028.

5 M. B. Kadiiska, B. C. Gladen, D. D. Baird, D. Germolec, L. B. Graham, C. E. Parker, A. Nyska, J. T. Wachsman, B. N. Ames, S. Basu, N. Brot, G. A. FitzGerald, R. A. Floyd, M. George, J. W. Heinecke, G. E. Hatch, K. Hensley, J. A. Lawson, L. J. Marnett, J. D. Morrow, D. M. Murray, J. Plastaras, L. J. Roberts Ii, J. Rokach, M. K. Shigenaga, R. S. Sohal, J. Sun, R. R. Tice, D. H. Van Thiel, D. Wellner, P. B. Walter, K. B. Tomer, R. P. Mason and J. C. Barrett, Biomarkers of Oxidative Stress Study II: Are oxidation products of lipids, proteins, and DNA markers of $\mathrm{CCl} 4$ poisoning?, Free Radical Biol. Med., 2005, 38, 698-710.

6 T. Durand, V. Bultel-Poncé, A. Guy, S. El Fangour, J. C. Rossi and J. M. Galano, Isoprostanes and phytoprostanes: Bioactive lipids, Biochimie, 2011, 93, 52-60.

7 J. D. Morrow, T. A. Minton, C. R. Mukundan, M. D. Campbell, W. E. Zackert, V. C. Daniel, K. F. Badr, I. A. Blair and L. J. Roberts Ii, Free radical-induced generation of isoprostanes in vivo: evidence for the formation of D-ring and E-ring isoprostanes, 1994.

$8 \mathrm{~J}$. R. Vane, Inhibition of prostaglandin synthesis as a mechanism of action for aspirin-like drugs, Nat. New Biol., 1971, 231, 232-235.

9 S. Medina, R. Domínguez-Perles, R. Cejuela-Anta, D. Villaño, J. M. Martínez-Sanz, P. Gil, C. García-Viguera, F. Ferreres, J. I. Gil and A. Gil-Izquierdo, Assessment of oxidative stress markers and prostaglandins after chronic training of triathletes, Prostaglandins Other Lipid Mediators, 2012, 99, 79-86.

10 C. D. Funk, Prostaglandins and leukotrienes: Advances in eicosanoid biology, Science, 2001, 294, 1871-1875.

11 J.-M. Galano, J. C.-Y. Lee, C. Gladine, B. Comte, J.-Y. Le Guennec, C. Oger and T. Durand, Non-enzymatic cyclic oxygenated metabolites of adrenic, docosahexaenoic, eicosapentaenoic and $\alpha$-linolenic acids; bioactivities and potential use as biomarkers, Biochim. Biophys. Acta, Mol. Cell Biol. Lipids, 2015, 1851, 446-455.

12 R. F. Guerrero, M. C. García-Parrilla, B. Puertas and E. Cantos-Villar, Wine, resveratrol and health: A review, Nat. Prod. Commun., 2009, 4, 635-658.

13 S. Renaud and M. De Lorgeril, Wine, alcohol, platelets, and the French paradox for coronary heart disease, Lancet, 1992, 339, 1523-1526.

14 A. A. A. Bertelli and D. K. Das, Grapes, wines, resveratrol, and heart health, J. Cardiovasc. Pharmacol., 2009, 54, 468476.
15 M. Mushtaq and S. M. Wani, Polyphenols and human health- A review, Int. J. Pharm. Biol. Sci., 2013, 4, 338-360.

16 H. Schröder, R. De La Torre, R. Estruch, D. Corella, M. A. Martínez-González, J. Salas-Salvadó, E. Ros, F. Arós, G. Flores, E. Civit, M. Farré, M. Fiol, J. Vila, J. FernandezCrehuet, V. Ruiz-Gutiérrez, J. Lapetra, G. Sáez and M. I. Covas, Alcohol consumption is associated with high concentrations of urinary hydroxytyrosol, Am. J. Clin. Nutr., 2009, 90, 1329-1335.

17 R. De La Torre, M. I. Covas, M. A. Pujadas, M. Fitó and M. Farré, Is dopamine behind the health benefits of red wine?, Eur. J. Nutr., 2006, 45, 307-310.

18 J. Mulero, P. Zafrilla, J. M. Cayuela, A. Martínez-Cachá and F. Pardo, Antioxidant activity and phenolic compounds in organic red wine using different winemaking techniques, J. Food Sci., 2011, 76, 436-440.

19 M. I. Fernández-Mar, R. Mateos, M. C. García-Parrilla, B. Puertas and E. Cantos-Villar, Bioactive compounds in wine: Resveratrol, hydroxytyrosol and melatonin: A review, Food Chem., 2012, 130, 797-813.

20 R. Hardeland and S. R. Pandi-Perumal, Melatonin, a potent agent in antioxidative defense: Actions as a natural food constituent, gastrointestinal factor, drug and prodrug, Nutr. Metab., 2005, 2, 22.

21 C. Vilaplana Peréz, D. Auñon Calles, L. A. García Flores and A. Gil-Izquierdo, Hydroxytyrosol and potential uses in cardiovascular diseases, cancer and AIDS, Front. Nutr., 2014, 1, 18.

22 M. A. Martin, S. Ramos, A. B. Granado-Serrano, I. Rodriguez-Ramiro, M. Trujillo, L. Bravo and L. Goya, Hydroxytyrosol induces antioxidant/detoxificant enzymes and Nrf2 translocation via extracellular regulated kinases and phosphatidylinositol-3-kinase/ protein kinase B pathways in HepG2 cells, Mol. Nutr. Food Res., 2010, 54, 956966.

23 V. Srinivasan, S. R. Pandi-Perumal, G. J. M. Maestroni, A. I. Esquifino, R. Hardeland and D. P. Cardinali, Role of melatonin in neurodegenerative diseases, Neurotoxic. Res., 2005, 7, 293-318.

24 Y. T. Wu, L. C. Lin and T. H. Tsai, Measurement of free hydroxytyrosol in microdialysates from blood and brain of anesthetized rats by liquid chromatography with fluorescence detection, J. Chromatogr., A, 2009, 1216, 35013507.

25 A. Guy, C. Oger, J. Heppekausen, C. Signorini, C. De Felice, A. Fürstner, T. Durand and J. M. Galano, Oxygenated Metabolites of n-3 Polyunsaturated Fatty Acids as Potential Oxidative Stress Biomarkers: Total Synthesis of 8-F3t-IsoP, 10-F4t-NeuroP and [D4]-10-F4t-NeuroP, Chem. - Eur. J., 2014, 20, 6374-6380.

26 T. Durand, A. Guy, J.-P. Vidal and J.-C. Rossi, Total Synthesis of (15 R)-and (15 S)-F2t-Isoprostanes by a Biomimetic Process Using the Cyclization of Acyclic Dihydroxylated Octa-5, 7-dienyl Radicals, J. Org. Chem., 2002, 67, 3615-3624. 
27 T. Durand, J.-L. Cracowski, A. Guy and J.-C. Rossi, Syntheses and preliminary pharmacological evaluation of the two epimers of the 5-F 2t-isoprostane, Bioorg. Med. Chem. Lett., 2001, 11, 2495-2498.

28 J. Marhuenda, S. Medina, P. Martínez-Hernández, S. Arina, P. Zafrilla, J. Mulero, H. G. Genieser, F. Ferreres and A. GilIzquierdo, Melatonin and hydroxytyrosol-rich wines influence the generation of DNA oxidation catabolites linked to mutagenesis after the ingestion of three types of wine by healthy volunteers, Food Funct., 2016, 7, 4781-4796.

29 J. Marhuenda, S. Medina, P. Martínez-Hernández, S. Arina, P. Zafrilla, J. Mulero, C. Oger, J.-M. Galano, T. Durand, F. Ferreres and A. Gil-Izquierdo, Melatonin and hydroxytyrosol protect against oxidative stress related to the central nervous system after the ingestion of three types of wine by healthy volunteers, Food Funct., 2017, 8, 64-74.

30 E. Cantos, J. C. Espín, M. J. Fernández, J. Oliva and F. A. Tomás-Barberán, Postharvest UV-C-irradiated grapes as a potential source for producing stilbene-enriched red wines, J. Agric. Food Chem., 2003, 51, 1208-1214.

31 R. Domínguez-Perles, D. Auñón, F. Ferreres and A. Gil-Izquierdo, Gender Differences on Plasma and Urine metabolites from Sprague-dawley Rats after Oral Administration of Normal and High Dose of Hydroxytyrosol, Hydroxytyrosol Acetate, and DOPAC, Eur. J. Nutr., 2015, 1-10, DOI: 10.1007/s00394-015-1071-2.

32 M. S. Fernández-Pachón, S. Medina, G. Herrero-Martín, I. Cerrillo, G. Berná, B. Escudero-López, F. Ferreres, F. Martín, M. C. García-Parrilla and A. Gil-Izquierdo, Alcoholic fermentation induces melatonin synthesis in orange juice, J. Pineal Res., 2014, 56, 31-38.

33 S. Medina, I. De Miguel-Elízaga, C. Oger, J.-M. Galano, T. Durand, M. Martínez-Villanueva, M. L. Gil-Del Castillo, I. Villegas-Martínez, F. Ferreres, P. Martínez-Hernández and Á. Gil-Izquierdo, Dihomo-isoprostanes -non-enzymatic metabolites of AdA- are higher in epileptic patients compared to healthy individuals by a new UHPLC-QqQ-MS/MS method, Free Radical Biol. Med., 2015, 79, 154-163.

34 C. Vigor, J. Bertrand-Michel, E. Pinot, C. Oger, J. Vercauteren, P. Le Faouder, J. M. Galano, J. C. Y. Lee and T. Durand, Non-enzymatic lipid oxidation products in biological systems: ASSESSMENT of the metabolites from polyunsaturated fatty acids, J. Chromatogr. B: Anal. Technol. Biomed. Life Sci., 2014, 964, 65-78.

35 J. Bouayed, H. Deußer, L. Hoffmann and T. Bohn, Bioaccessible and dialysable polyphenols in selected apple varieties following in vitro digestion $v s$. their native patterns, Food Chem., 2012, 131, 1466-1472.

36 J. Bouayed, L. Hoffmann and T. Bohn, Total phenolics, flavonoids, anthocyanins and antioxidant activity following simulated gastro-intestinal digestion and dialysis of apple varieties: Bioaccessibility and potential uptake, Food Chem., 2011, 128, 14-21.

37 D. Tagliazucchi, E. Verzelloni, D. Bertolini and A. Conte, In vitro bio-accessibility and antioxidant activity of grape polyphenols, Food Chem., 2010, 120, 599-606.
38 S. Talavéra, C. Felgines, O. Texier, C. Besson, A. GilIzquierdo, J.-L. Lamaison and C. Rémésy, Anthocyanin metabolism in rats and their distribution to digestive area, kidney, and brain, J. Agric. Food Chem., 2005, 53, 3902-3908.

39 A. E. Barden, K. D. Croft, T. Durand, A. Guy, M. J. Mueller and T. A. Mori, Flaxseed oil supplementation increases plasma F1-phytoprostanes in healthy men, J. Nutr., 2009, 139, 1890-1895.

40 A. Basli, S. Soulet, N. Chaher, J. M. Mérillon, M. Chibane, J. P. Monti and T. Richard, Wine polyphenols: Potential agents in neuroprotection, Oxid. Med. Cell. Longevity, 2012, 805762.

41 M. I. Rodríguez-Naranjo, A. Gil-Izquierdo, A. M. Troncoso, E. Cantos-Villar and M. C. Garcia-Parrilla, Melatonin is synthesised by yeast during alcoholic fermentation in wines, Food Chem., 2011, 126, 1608-1613.

42 M. P. Gómez-Serranillos, S. Martín, T. Ortega, O. M. Palomino, M. Prodanov, V. Vacas, T. Hernández, I. Estrella and M. E. Carretero, Study of red wine neuroprotection on astrocytes, Plant Foods Hum. Nutr., 2009, 64, 238-243.

43 C. Vilaplana-Pérez, D. Auñón, L. A. García-Flores and A. Gil-Izquierdo, Hydroxytyrosol and Potential Uses in Cardiovascular Diseases, Cancer, and AIDS, Front. Nutr., 2014, 1, 18.

44 E. Ricciotti and G. A. Fitzgerald, Prostaglandins and inflammation, Arterioscler., Thromb., Vasc. Biol., 2011, 31, 986-1000.

45 R. A. Lewis, N. A. Soter and P. T. Diamond, Prostaglandin D2 generation after activation of rat and human mast cells with anti-IgE, J. Immunol., 1982, 129, 1627-1631.

46 Y. Urade, M. Ujihara, Y. Horiguchi, K. Ikai and O. Hayaishi, The major source of endogenous prostaglandin D2 production is likely antigen-presenting cells. Localization of glutathione-requiring prostaglandin D synthetase in histiocytes, dendritic, and Kupffer cells in various rat tissues, J. Immunol., 1989, 143, 2982-2989.

47 W. L. Smith, Y. Urade and P. J. Jakobsson, Enzymes of the cyclooxygenase pathways of prostanoid biosynthesis, Chem. Rev., 2011, 111, 5821-5865.

48 D. W. Gilroy, P. R. Colville-Nash, D. Willis, J. Chivers, M. J. Paul-Clark and D. A. Willoughby, Inducible cyclooxygenase may have anti-inflammatory properties, Nat. Med., 1999, 5, 698-701.

49 M. Noda, Y. Kariura, U. Pannasch, K. Nishikawa, L. Wang, T. Seike, M. Ifuku, Y. Kosai, B. Wang, C. Nolte, S. Aoki, H. Kettenmann and K. Wada, Neuroprotective role of bradykinin because of the attenuation of pro-inflammatory cytokine release from activated microglia, J. Neurochem., 2007, 101, 397-410.

50 P. Libby, S. J. C. Warner and G. B. Friedman, Interleukin 1: A mitogen for human vascular smooth muscle cells that induces the release of growth-inhibitory prostanoids, J. Clin. Invest., 1988, 81, 487-498.

51 C. E. Trebino, J. L. Stock, C. P. Gibbons, B. M. Naiman, T. S. Wachtmann, J. P. Umland, K. Pandher, J. M. Lapointe, 
S. Saha, M. L. Roach, D. Carter, N. A. Thomas, B. A. Durtschi, J. D. McNeish, J. E. Hambor, P. J. Jakobsson, T. J. Carty, J. R. Perez and L. P. Audoly, Impaired inflammatory and pain responses in mice lacking an inducible prostaglandin E synthase, Proc. Natl. Acad. Sci. U. S. A., 2003, 100, 9044-9049.

52 S. Thorén and P. J. Jakobsson, Coordinate up- and downregulation of glutathione-dependent prostaglandin $\mathrm{E}$ synthase and cyclooxygenase-2 in A549 cells: Inhibition by NS-398 and leukotriene C4, Eur. J. Biochem., 2000, 267, 6428-6434.

53 T. Moriyama, T. Higashi, K. Togashi, T. Iida, E. Segi, Y. Sugimoto, T. Tominaga, S. Narumiya and M. Tominaga, Sensitization of TRPVI by EP1 and IP reveals peripheral nociceptive mechanism of prostaglandins, Mol. Pain, 2005, $1,3$.

54 W. K. Pollock, R. A. Armstrong, L. J. Brydon, R. L. Jones and D. E. MacIntyre, Thromboxane-induced phosphatidate formation in human platelets. Relationship to receptor occupancy and to changes in cytosolic free calcium, Biochem. J., 1984, 219, 833-842.

55 R. A. Coleman, P. P. A. Humphrey, I. Kennedy, G. P. Levy and P. Lumley, Comparison of the actions of U-46619, a prostaglandin $\mathrm{H} 2$-analogue, with those of prostaglandin $\mathrm{H} 2$ and thromboxane A2 on some isolated smooth muscle preparations, Br. J. Pharmacol., 1981, 73, 773-778.

56 R. A. Coleman and R. L. G. Sheldrick, Prostanoid-induced contraction of human bronchial smooth muscle is mediated by TP-receptors, Br. J. Pharmacol., 1989, 96, 688692.

57 N. M. Lepak and G. Serrero, Inhibition of adipose differentiation by $9 \alpha, 11 \beta$-prostaglandin F $2 \alpha$, Prostaglandins, 1993, 46, 511-517.

58 A. Greenhough, H. J. M. Smartt, A. E. Moore, H. R. Roberts, A. C. Williams, C. Paraskeva and A. Kaidi, The COX-2/PGE2 pathway: Key roles in the hallmarks of cancer and adaptation to the tumour microenvironment, Carcinogenesis, 2009, 30, 377-386.

59 P. M. Olley and F. Coceani, Prostaglandins and the ductus arteriosus, Annu. Rev. Med., 1981, 32, 375-385.

60 R. B. Cole, S. Abman and K. U. Aziz, Prolonged prostaglandin E1 infusion: Histologic effects on the patent ductus arteriosus, Pediatrics, 1981, 67, 816-819.

61 K. J. Rabbani, F. Tauqeer and R. Rabbani, ProstaglandinE1 for the medical management of erectile dysfunction, Pak. J. Med. Health Sci., 2010, 4, 512. 